\title{
Electrodeposition-Based Fabrication and Characteristics of Tungsten Trioxide Thin Film
}

\author{
Li Lin, ${ }^{1}$ Chin-Pao Cheng, ${ }^{2}$ and Tun-Ping Teng ${ }^{1}$ \\ ${ }^{1}$ Department of Industrial Education, National Taiwan Normal University, No. 162, Section 1, He-ping E. Road, \\ Da-an District, Taipei City 10610, Taiwan \\ ${ }^{2}$ Department of Mechatronic Engineering, National Taiwan Normal University, No. 162, Section 1, He-ping E. Road, \\ Da-an District, Taipei City 10610, Taiwan \\ Correspondence should be addressed to Tun-Ping Teng; tube5711@ntnu.edu.tw
}

Received 28 November 2015; Revised 18 February 2016; Accepted 29 March 2016

Academic Editor: Zainovia Lockman

Copyright (C) $2016 \mathrm{Li}$ Lin et al. This is an open access article distributed under the Creative Commons Attribution License, which permits unrestricted use, distribution, and reproduction in any medium, provided the original work is properly cited.

In this study, tungsten trioxide $\left(\mathrm{WO}_{3}\right)$ thin films were electrodeposited on indium tin oxide (ITO) glass to form $\mathrm{WO}_{3}$-coated glass. The electrodeposition (ED) time $\left(t_{\mathrm{ED}}\right)$ and $\mathrm{ED}$ current $\left(I_{\mathrm{ED}}\right)$ were varied to control the film thickness and morphology. Furthermore, the crystallization of the thin films was controlled by annealing them at $250^{\circ} \mathrm{C}, 500^{\circ} \mathrm{C}$, and $700^{\circ} \mathrm{C}$. The results showed that the thickness of the $\mathrm{WO}_{3}$ thin films increased with $t_{\mathrm{ED}}$ and $I_{\mathrm{ED}}$. The as-deposited thin films and those annealed at $250^{\circ} \mathrm{C}$ were amorphous, whereas the $\mathrm{WO}_{3}$ thin films annealed at 500 and $700^{\circ} \mathrm{C}$ were in the anorthic phase. Moreover, the amorphous $\mathrm{WO}_{3}$-coated glass exhibited high transmittance in visible light and low transmittance in near-infrared light, whereas the anorthic $\mathrm{WO}_{3}$-coated glass had high transmittance in near-infrared light. An empirical formula for determining the thickness of $\mathrm{WO}_{3}$ thin films was derived through multiple regressions of the ED process parameters.

\section{Introduction}

Tungsten trioxide $\left(\mathrm{WO}_{3}\right)$ is a transition metal oxide and an n-type semiconductor. Different forms of crystalline have unique optical, electrical, and magnetic properties and are widely used in various fields. $\mathrm{WO}_{3}$ has electrochromic properties and is widely used in reversible electrochromic elements, smart windows, and mirrors [1-7]. It also shows high catalytic performance in degrading contaminants, often in combination with $\mathrm{TiO}_{2}, \mathrm{Pt}, \mathrm{Ag}, \mathrm{Na}^{+}$, and other materials [8-11]. Furthermore, $\mathrm{WO}_{3}$ is used in gas sensors because of its sensitivity to various gases such as $\mathrm{CO}$, ethanol gas, $\mathrm{NH}_{3}, \mathrm{NO}_{x}$, ozone, and toluene gas [12-16]. In addition to the aforementioned applications, $\mathrm{WO}_{3}$ can be used in lithiumion battery electrodes [17-20] and for lubricating mechanical components [21-23] to improve their operating performance. Therefore, $\mathrm{WO}_{3}$ has high potential for use in developing multifunctional materials. Because of their characteristics, $\mathrm{WO}_{3}$ materials can be employed to modify traditional materials and endow them with specific characteristics to improve their performance.

$\mathrm{WO}_{3}$ thin films are typically fabricated using such methods as chemical vapor deposition $[12,24]$, sputtering $[5,6$, $16]$, screen printing $[12,14]$, and electrodeposition (ED) [1$3,25,26]$. ED involves a simple setup, is inexpensive, does not require special atmospheric conditions, and can easily form thin films on irregularly shaped substrates. $\mathrm{WO}_{3}$ thin films can be fabricated by using peroxotungstic acid in the ED process, and their thickness and morphology can be controlled by varying the ED voltage $\left(V_{\mathrm{ED}}\right)$, current $\left(I_{\mathrm{ED}}\right)$, and time $\left(t_{\mathrm{ED}}\right)$. Generally, ED is commonly used along with a three-electrode electrochemical cell in preparing a $\mathrm{WO}_{3}$ thin film [1-3, 25-27].

In this study, ED using a two-electrode method was employed to fabricate a $\mathrm{WO}_{3}$ thin film on an indium tin oxide (ITO) glass substrate. The ED of the two-electrode method has advantages of lower equipment cost and higher deposition rate than the three-electrode electrochemical cell. 
By adjustment of the $t_{\mathrm{ED}}$ and $I_{\mathrm{ED}}$, the structure, thickness, and morphology of the thin films were controlled. Furthermore, the crystallization of the thin films was controlled by annealing them at various temperatures $\left(T_{a}\right)$. Finally, an ultravioletvisible-near-infrared (UV-VIS-NIR) spectrometer was used to determine the spectral characteristics of the $\mathrm{WO}_{3}$-coated glass.

\section{Preparation of $\mathrm{WO}_{3}$ Thin Films}

The primary materials used for preparing peroxotungstic acid were tungsten metal powder (particle size: $12 \mu \mathrm{m}$; purity: 99.9\%; Acros, Belgium) and a low concentration (34.5\%$36.5 \%)$ of hydrogen peroxide $\left(\mathrm{H}_{2} \mathrm{O}_{2}\right.$, Sigma-Aldrich, Germany). Dissolving $3.0 \mathrm{~g}$ of tungsten metal powder in $30 \mathrm{~mL}$ of $\mathrm{H}_{2} \mathrm{O}_{2}$ yielded a colorless peroxotungstic acid solution. The exothermic reaction was conducted by cooling the acid solution in an isothermal unit (P-10, YSC, Taiwan) between $5^{\circ} \mathrm{C}$ and $10^{\circ} \mathrm{C}$. The reaction formula for peroxotungstic acid preparation is as follows $[25,27]$ :

$$
2 \mathrm{~W}+10 \mathrm{H}_{2} \mathrm{O}_{2} \longrightarrow \mathrm{W}_{2} \mathrm{O}_{11}{ }^{2-}+2 \mathrm{H}^{+}+9 \mathrm{H}_{2} \mathrm{O}
$$

When the exothermic reaction was completed, the solution was filtered using filter paper (pore size, $10-\mu \mathrm{m}$ ) to remove the unreacted tungsten powder. The obtained clear solution was combined with $30 \mathrm{~mL}$ of $99.7 \%$ glacial acetic acid $\left(\mathrm{CH}_{3} \mathrm{COOH}\right.$, Showa, Japan), and the resulting solution was refluxed at $55^{\circ} \mathrm{C}$ for $12 \mathrm{~h}$ to decompose excess $\mathrm{H}_{2} \mathrm{O}_{2}$ and acetylate the peroxotungstic acid. Refluxing the peroxotungstic acid strengthened the adhesion between the thin film and the substrate [1]. Finally, the refluxed peroxotungstic acid was mixed with $60 \mathrm{~mL}$ of anhydrous absolute ethanol to produce a pale yellow coating solution for the ED.

Figure 1 shows the experimental setup used in this study. To adjust the electrode distance $(20 \mathrm{~mm})$, a platinum plate and ITO glass substrate ( $7 \Omega / \mathrm{cm}^{2}, 1737$, Corning, USA) were fixed to a polypropylene holder as the positive and negative electrodes. The holder was placed in a glass tank containing a thermoelectric module and temperature controller. Prior to ED, the ITO glass was cleaned to remove contaminants and improve the adhesion between the ITO glass surface and $\mathrm{WO}_{3}$ thin film. The ITO glass was cleaned in acetone for $20 \mathrm{~min}$ in an ultrasonic bath (5510R-DTH, Branson, USA), rinsed with deionized water, dried in nitrogen $\left(\mathrm{N}_{2}, 99.995 \%\right)$, and heated to $60^{\circ} \mathrm{C}$ for $15 \mathrm{~min}$ on a hot plate (PC-420D, Corning, USA).

The platinum plate and ITO glass electrodes measured $30 \mathrm{~mm} \times 20 \mathrm{~mm} \times 0.8 \mathrm{~mm}(\mathrm{~L} \times \mathrm{W} \times$ Thickness $)$ and $20 \mathrm{~mm}$ $\times 20 \mathrm{~mm} \times 0.6 \mathrm{~mm}(\mathrm{~L} \times \mathrm{W} \times$ Thickness $)$, respectively; the length of the electrode immersed in the coating solution was $18 \mathrm{~mm}$. Therefore, the effective area of platinum plate and ITO glass electrodes for ED was approximately 7.5 and $3.6 \mathrm{~cm}^{2}$, respectively. Through $\mathrm{ED}, \mathrm{a} \mathrm{WO}_{3}$ thin film was formed on the ITO glass (negative electrode). Because the coating solution temperature affects the electrochemical reaction, the thermoelectric module was necessary to maintain the coating solution temperature at $15^{\circ} \mathrm{C}$ to preserve the stability and reproducibility of the $\mathrm{WO}_{3}$ thin-film fabrication process.
This study used ED along with two-electrode equipment (programmable DC power supply) and a constant $I_{\mathrm{ED}}$ process for preparing a $\mathrm{WO}_{3}$ thin film on ITO glass. This approach is advantageous because it involves low equipment costs and a simple process and achieves a relatively stable coating rate. The reaction formula of ED with peroxotungstic acid for the $\mathrm{WO}_{3}$ thin-film preparation is as follows $[25,27]$ :

$$
\mathrm{W}_{2} \mathrm{O}_{11}{ }^{2-}+2 \mathrm{H}^{+} \longrightarrow 2 \mathrm{WO}_{3}+2 \mathrm{O}_{2}+\mathrm{H}_{2} \mathrm{O}
$$

In the ED process, a programmable DC power supply (PSS-3203, GW Instek, Taiwan) was used to maintain a constant $I_{\mathrm{ED}}(3,5,7$, and $9 \mathrm{~mA})$ for various $t_{\mathrm{ED}}(30,40$, 50 , and $60 \mathrm{~s}$ ). The current density for 3, 5, 7, and $9 \mathrm{~mA}$ of $I_{\mathrm{ED}}$ on the ITO electrode was approximately $0.83,1.39$, 1.94 , and $2.50 \mathrm{~mA} / \mathrm{cm}^{2}$, respectively. After the thin films were fabricated, the $\mathrm{WO}_{3}$-coated glass was cleaned by rinsing it with deionized water, drying it in $\mathrm{N}_{2}$, and heating it to $60^{\circ} \mathrm{C}$ for $10 \mathrm{~min}$ on a hot plate. $\mathrm{WO}_{3}$-coated glass samples were selected on the basis of preferred ED process parameters, which were determined according to the morphology of the $\mathrm{WO}_{3}$ thin films; the morphology was observed using visually and optical microscope. The selected $\mathrm{WO}_{3}$-coated glass samples were annealed at $250^{\circ} \mathrm{C}, 500^{\circ} \mathrm{C}$, and $700^{\circ} \mathrm{C}$ for one hour. The annealing temperatures of $250^{\circ} \mathrm{C}, 500^{\circ} \mathrm{C}$, and $700^{\circ} \mathrm{C}$ for $\mathrm{WO}_{3}$-coated glass mainly referred to the literature $[1-3,28,29]$. In general, in the annealing temperature of $350-550^{\circ} \mathrm{C}$, the monoclinic $\mathrm{WO}_{3}$ phase was naturally formed, while the formation of triclinic (anorthic) $\mathrm{WO}_{3}$ phase was induced in the annealing temperature ranging from $550^{\circ} \mathrm{C}$ to $750^{\circ} \mathrm{C}$. Above $750^{\circ} \mathrm{C}$, the $\mathrm{WO}_{3}$ phase can be changed to orthorhombic phase [6]. The annealed samples were then cleaned according to the aforementioned procedure. The ED process parameters are listed in Table 1. For each process parameter, three samples were prepared for testing to ensure the reproducibility and reliability of the relevant experiments.

\section{Characterization}

The surface morphologies of the $\mathrm{WO}_{3}$ thin films were analyzed using a high-resolution field-emission scanning electron microscope (FESEM, S-4800, Hitachi, Japan). Crystallization was analyzed using a multifunction high-power X-ray diffractometer (XRD, D8 Discover SSS, Bruker, the Netherlands) with $\mathrm{Cu} \mathrm{K} \alpha$ radiation, and all peaks measured by XRD were assigned by comparing them with those in the data of the International Centre for Diffraction Data [29].

The thickness of the $\mathrm{WO}_{3}$ thin films was determined by the height of film cross section, which was measured using the FESEM. The high magnification of the film cross section caused the observation range to be very small, which limited the representative of the film thickness. Therefore, the $\mathrm{WO}_{3}$ film thickness was also measured with a thin-film analyzer (F10-RT, Filmetric, USA); the measurement principle in this instrument is based on light interference in thin films. The crystallization will affect the refractive index and surface roughness of $\mathrm{WO}_{3}$ thin film, thereby affecting the accuracy of the thickness of a $\mathrm{WO}_{3}$ thin film measured by a thinfilm analyzer. Therefore, the relevant setting parameters of 


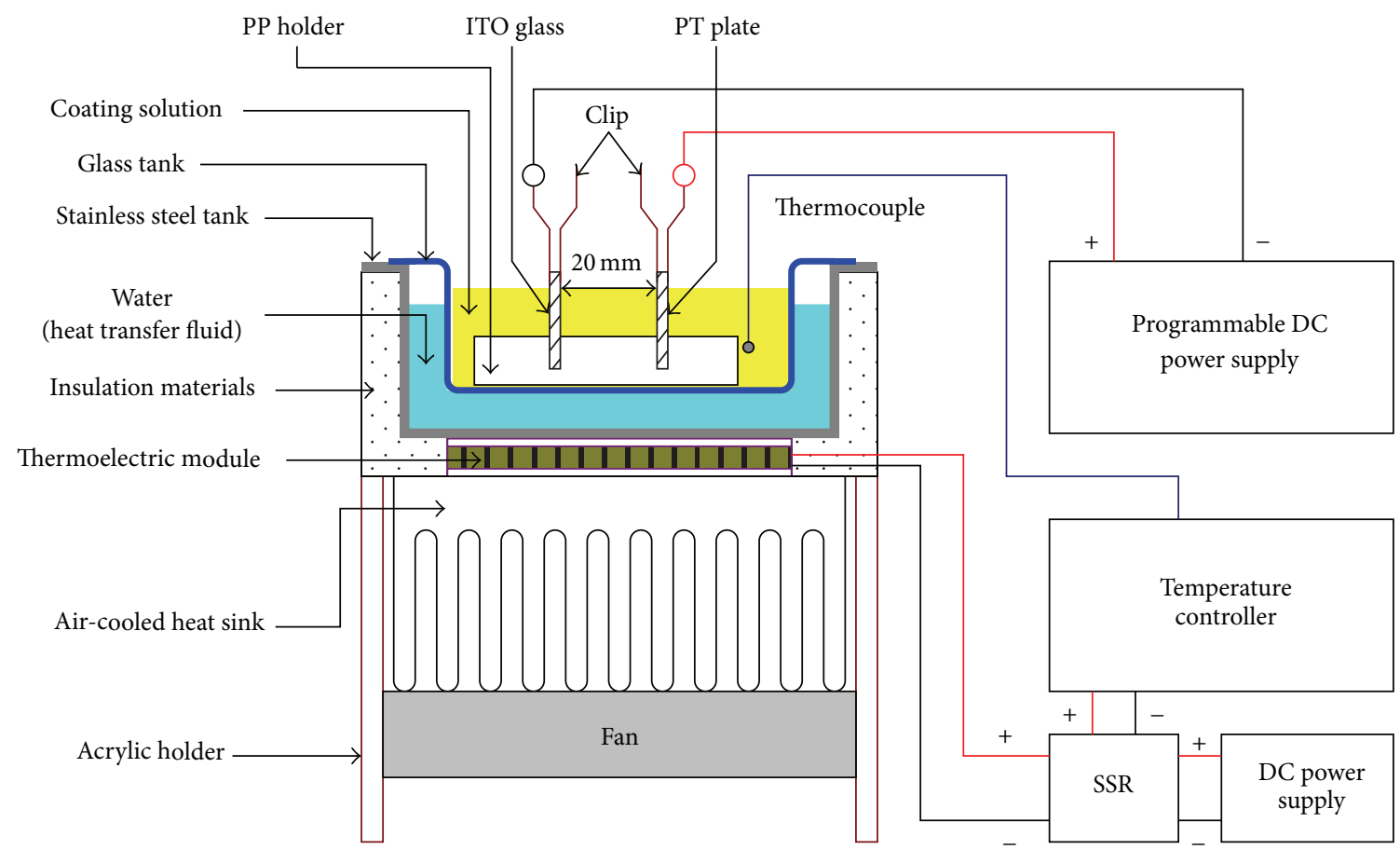

Figure 1: Experimental setup for ED.

TABLE 1: Process parameters of ED for the $\mathrm{WO}_{3}$ thin films.

\begin{tabular}{lccc}
\hline Number & $I_{\mathrm{ED}}(\mathrm{mA})$ & $t_{\mathrm{ED}}(\mathrm{sec})$. & $T_{a}\left({ }^{\circ} \mathrm{C}\right)^{*}$ \\
\hline 1 & & 30 & As-deposited \\
2 & 3 & 40 & 250 \\
3 & & 50 & 500 \\
4 & & 60 & 700 \\
\hline 5 & 5 & 30 & As-deposited \\
6 & & 40 & 250 \\
7 & & 50 & 500 \\
8 & & 60 & 700 \\
\hline 9 & & 30 & As-deposited \\
10 & & 40 & 250 \\
11 & & 50 & 500 \\
12 & & 60 & 700 \\
\hline 13 & 9 & 30 & As-deposited \\
14 & & 40 & 250 \\
15 & & 50 & 700 \\
16 & & 60 & 500 \\
\hline
\end{tabular}

* Only selected $\mathrm{WO}_{3}$ coated glass to be annealed.

the thin-film analyzer were corrected according to the test results of cross sections of the $\mathrm{WO}_{3}$ thin film measured by a FESEM to reduce the effects of refractive index and surface and roughness of the $\mathrm{WO}_{3}$ thin film on thickness measurement. To minimize measurement deviations, each fabricated process parameter (for three samples) for the film thickness involved three measurements (one measurement of the cross section by using the FESEM and two measurements of the thickness with the thin-film analyzer; each process parameter consists of a total of nine measured data). The five most concentrated measurements were then averaged, and this value was considered the experimental value of the samples.

The optical characteristics of $\mathrm{WO}_{3}$-coated glass for various process parameters were measured using a UV-VISNIR spectrometer (V-670, Jasco, Japan) with an integrating sphere (ISN-723, Jasco, Japan) to measure transmittance and reflectivity changes at wavelengths between 300 and $2400 \mathrm{~nm}$ at room temperature.

\section{Results and Discussions}

Figure 2 displays a photograph of a $\mathrm{WO}_{3}$-coated glass sample, along with various process parameters. The lower edge of the sample shows discoloration or stripping when the $I_{\mathrm{ED}}$ is higher than $5 \mathrm{~mA}$. Therefore, process parameters corresponding to the $I_{\mathrm{ED}}$ values of 3 and $5 \mathrm{~mA}$ (range of the red dotted line) were considered in the subsequent experiments.

Figure 3 shows FESEM images of a $\mathrm{WO}_{3}$ thin film, along with various process parameters. An increase in $I_{\mathrm{ED}}$ and $t_{\mathrm{ED}}$ increased the surface roughness of the as-deposited $\mathrm{WO}_{3}$ thin film (Figure 3(a)). This observation was attributed to the ED rate increasing with $I_{\mathrm{ED}}$, which caused the surface of the $\mathrm{WO}_{3}$ thin film to become increasingly uneven. In addition, the circuit impedance increased with the deposited film thickness, resulting in an unstable ED rate at long $t_{\mathrm{ED}}$. Generally, a constant current leads to a relatively stable ED rate. However, the circuit impedance at each point on the thin-film surface during ED is affected by the uniformity of the film thickness and can cause the ED rate to fluctuate, which further affects 


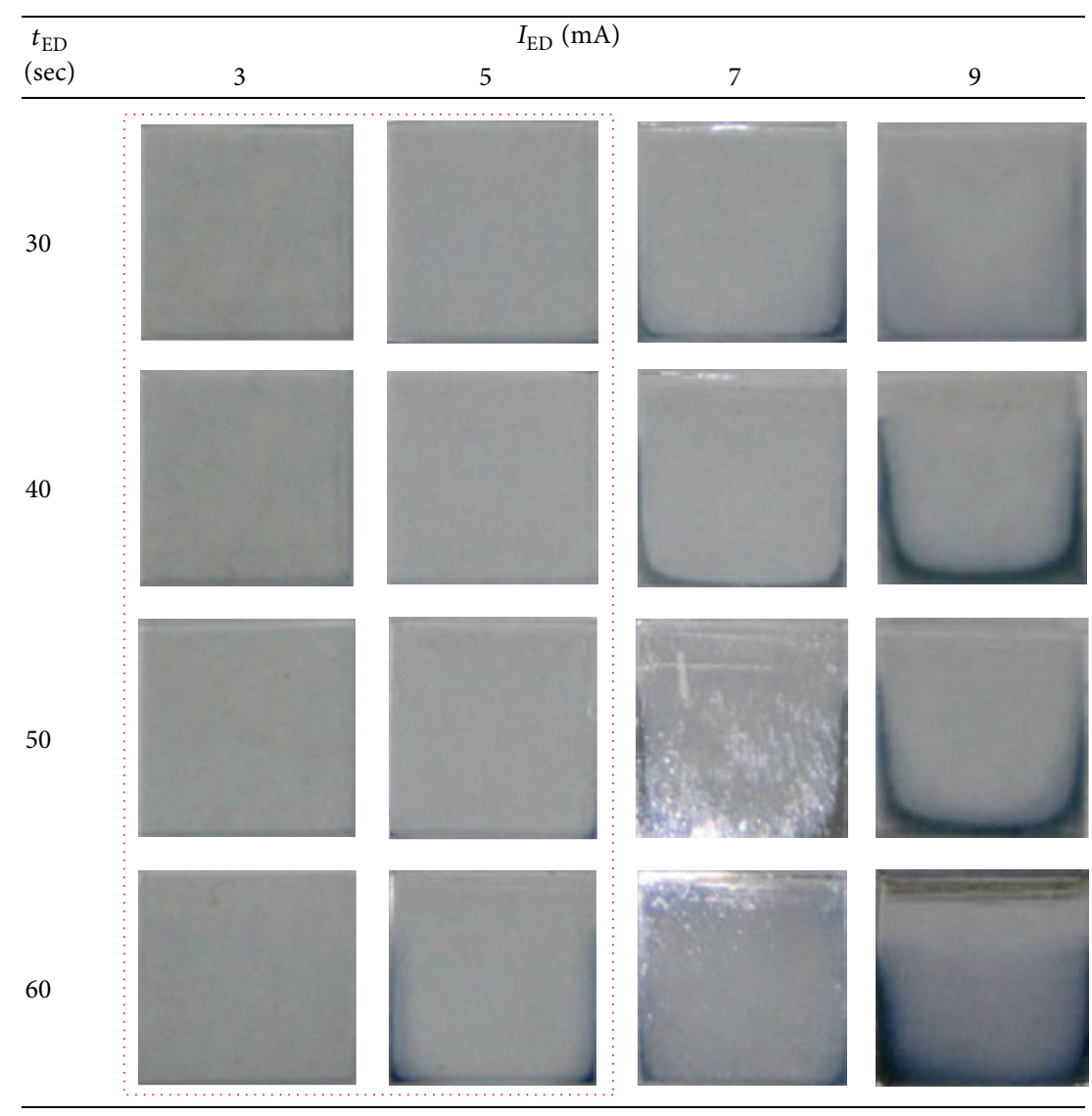

FIGURE 2: Photograph of the $\mathrm{WO}_{3}$-coated glass, along with various process parameters.

the surface roughness and uniformity of the deposited film. The relationship between the crystallization of the $\mathrm{WO}_{3}$ thin film and $T_{a}$ can be analyzed as follows. In Figure 3(b), at $T_{a}=250^{\circ} \mathrm{C}$, the surface morphologies of the $\mathrm{WO}_{3}$ thin films become compact, but no notable crystallization occurs. When the $T_{a}$ were 500 and $700^{\circ} \mathrm{C}$, crystallization and crystal growth were evident (Figures 3(c) and 3(d)).

The diffraction patterns in Figures 4 and 5 show only the effect of the crystallization at various $T_{a}$ at $t_{\mathrm{ED}}=60 \mathrm{~s}$. The reason for selecting this $t_{\mathrm{ED}}$ is that changes in the crystallization are easier to measure accurately in thicker films, and there is less interference in the diffraction signals from the substrate (ITO glass). The $\mathrm{WO}_{3}$ thin films grown at the as-deposited temperature and at $T_{a}=250^{\circ} \mathrm{C}$ did not show any crystallinity and were amorphous [27]. However, after annealing at 500 and $700^{\circ} \mathrm{C}$, the anorthic (triclinic) phase (PDF numbers: 20-1323) [2,3] appeared; this was seen in the diffraction pattern, and the XRD and FESEM analyses yielded the same result at this $T_{a}$. The intensity of the $\left(\begin{array}{lll}2 & 0 & 0\end{array}\right)$ peak increased with $T_{a}$ and $I_{\mathrm{ED}}$, mainly because a higher $I_{\mathrm{ED}}$ leads to a thicker $\mathrm{WO}_{3}$ thin film at a given $t_{\mathrm{ED}}$, and a high $T_{a}$ results in the formation of an almost perfectly crystalline $\mathrm{WO}_{3}$ thin film.

Figure 6 is a cross-sectional FESEM image of the $\mathrm{WO}_{3}$ coated glass annealed at 250,500 , and $700^{\circ} \mathrm{C}$. The cross section shows a three-layer structure comprising $\mathrm{WO}_{3}$, ITO, and glass. Defects formed in the glass substrate at $T_{a}=$ $700^{\circ} \mathrm{C}$ may result from some ingredients or impurities melted in the glass substrate. Defects could affect the experimental determination of the optical characteristics and film thickness, which were measured using a spectrometer and thinfilm analyzer. Therefore, the $\mathrm{WO}_{3}$-coated glass annealed at $700^{\circ} \mathrm{C}$ was omitted from the subsequent measurements of the optical characteristics and film thickness.

Figure 7 shows the variation of $\mathrm{WO}_{3}$ film thickness with various process parameters. The $\mathrm{WO}_{3}$ film thickness increases with $t_{\mathrm{ED}}$ and $I_{\mathrm{ED}}$. However, the $T_{a}$ substantially affected the $\mathrm{WO}_{3}$ film thickness. The thicknesses of the asdeposited $\mathrm{WO}_{3}$ thin films at $I_{\mathrm{ED}}$ values of 3 and $5 \mathrm{~mA}$ were 132.8 and $216.1 \mathrm{~nm}$ at $t_{\mathrm{ED}}=60 \mathrm{~s}$, respectively, and the ED rate was considerably high. The moisture of the $\mathrm{WO}_{3}$ thin film was removed, and the film became compact at $T_{a}=$ $250^{\circ} \mathrm{C}$; thereby, its average film thickness decreased. As the annealing temperature was raised to $500^{\circ} \mathrm{C}$, some parts of the crystals grew larger to make the $\mathrm{WO}_{3}$ thin film become thicker at these parts but thinner at other parts, exhibiting an uneven morphology of the thin-film surface (Figure 3(c)) and increased average film thickness of $\mathrm{WO}_{3}$. In addition, increase in the film thickness of $\mathrm{WO}_{3}$ may result from change of the structure in the process of crystalline phase transition for $\mathrm{WO}_{3}$ thin film. The multiple regressions for deriving an empirical formula for the film thickness showed that the $t_{\mathrm{ED}}$ 


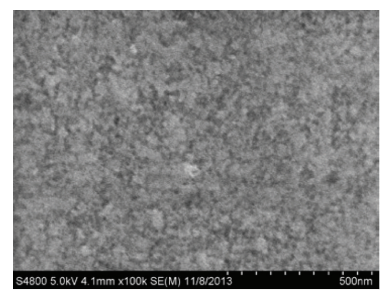

$3 \mathrm{~mA} / 30 \mathrm{sec}$

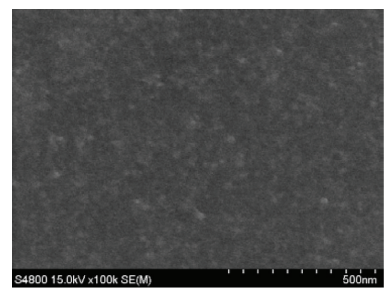

$5 \mathrm{~mA} / 30 \mathrm{sec}$

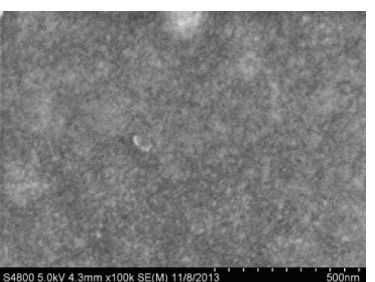

$3 \mathrm{~mA} / 30 \mathrm{sec}$

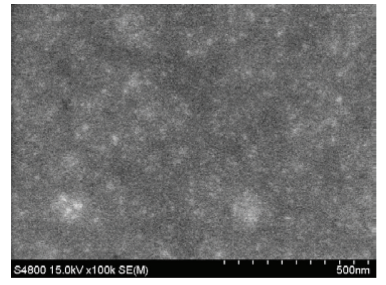

$5 \mathrm{~mA} / 30 \mathrm{sec}$

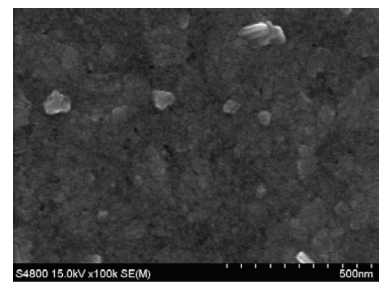

$3 \mathrm{~mA} / 30 \mathrm{sec}$

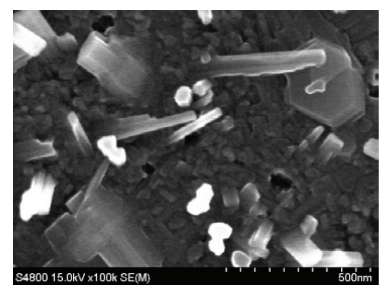

$5 \mathrm{~mA} / 30 \mathrm{sec}$

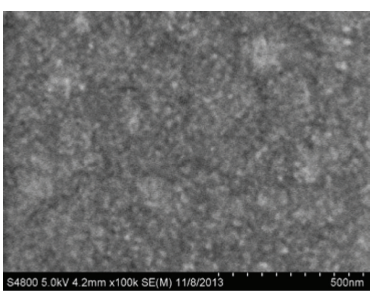

$3 \mathrm{~mA} / 40 \mathrm{sec}$

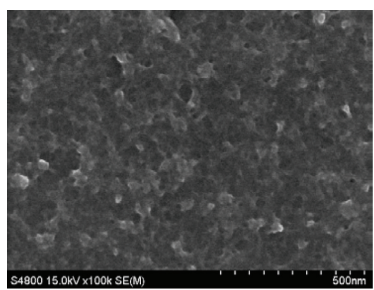

$5 \mathrm{~mA} / 40 \mathrm{sec}$

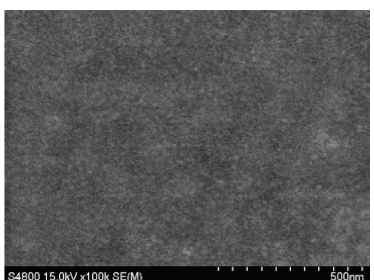

$3 \mathrm{~mA} / 40 \mathrm{sec}$

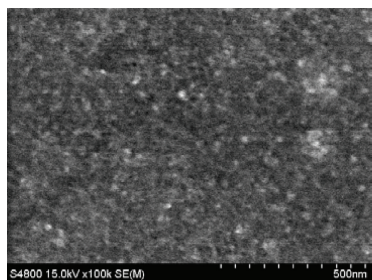

$5 \mathrm{~mA} / 40 \mathrm{sec}$

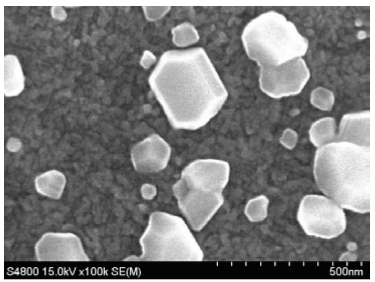

$3 \mathrm{~mA} / 40 \mathrm{sec}$

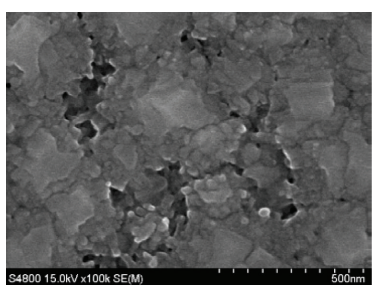

$5 \mathrm{~mA} / 40 \mathrm{sec}$

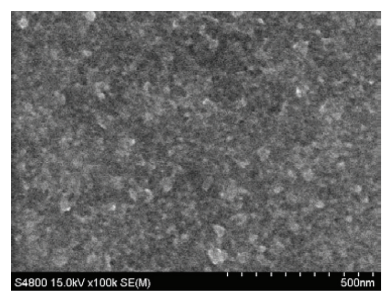

$3 \mathrm{~mA} / 50 \mathrm{sec}$

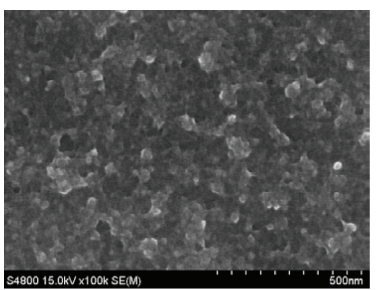

$5 \mathrm{~mA} / 50 \mathrm{sec}$

(a)

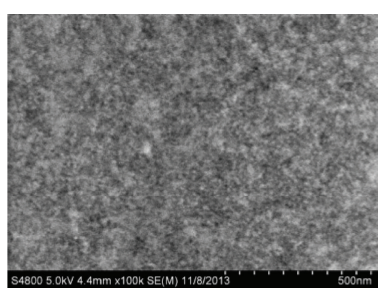

$3 \mathrm{~mA} / 50 \mathrm{sec}$

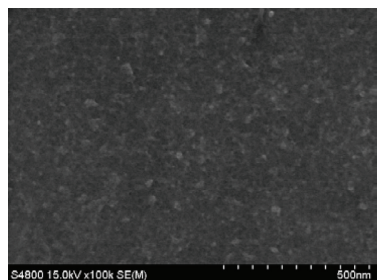

$5 \mathrm{~mA} / 50 \mathrm{sec}$

(b)

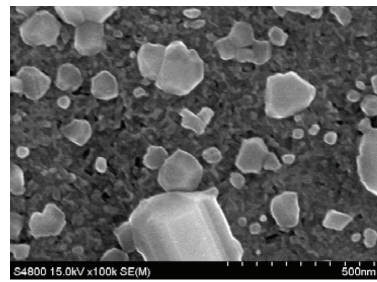

$3 \mathrm{~mA} / 50 \mathrm{sec}$

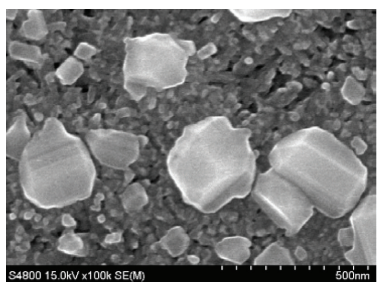

$5 \mathrm{~mA} / 50 \mathrm{sec}$

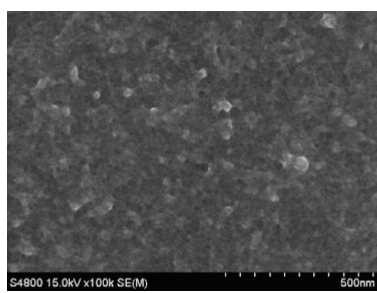

$3 \mathrm{~mA} / 60 \mathrm{sec}$

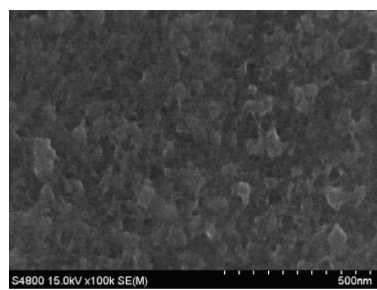

$5 \mathrm{~mA} / 60 \mathrm{sec}$

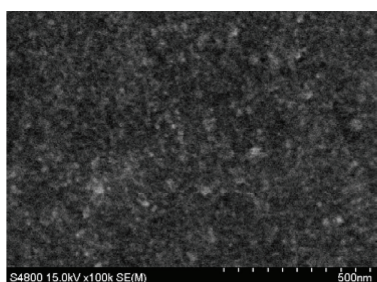

$3 \mathrm{~mA} / 60 \mathrm{sec}$

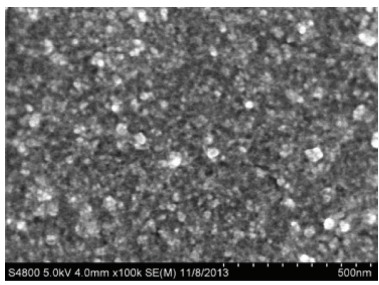

$5 \mathrm{~mA} / 60 \mathrm{sec}$

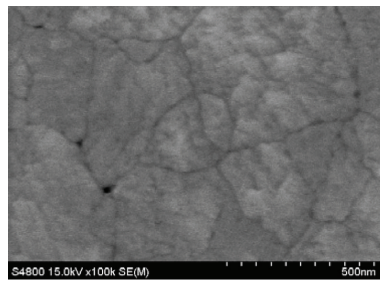

$3 \mathrm{~mA} / 60 \mathrm{sec}$

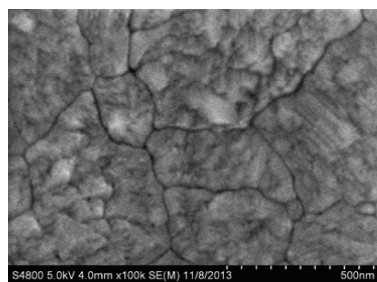

$5 \mathrm{~mA} / 60 \mathrm{sec}$

(c)

Figure 3: Continued. 


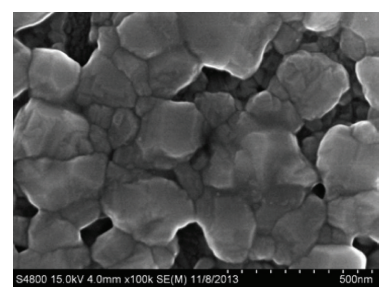

$3 \mathrm{~mA} / 30 \mathrm{sec}$

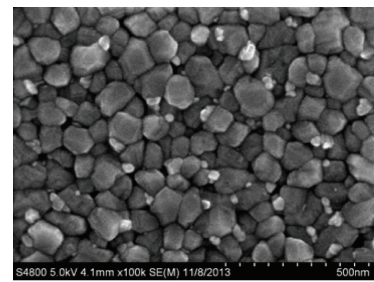

$5 \mathrm{~mA} / 30 \mathrm{sec}$

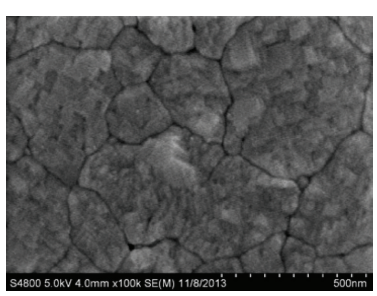

$3 \mathrm{~mA} / 40 \mathrm{sec}$

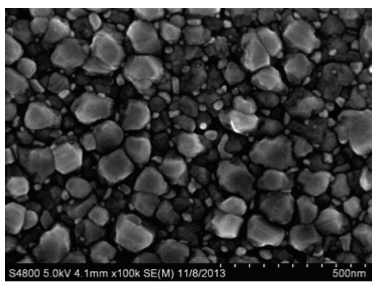

$5 \mathrm{~mA} / 40 \mathrm{sec}$

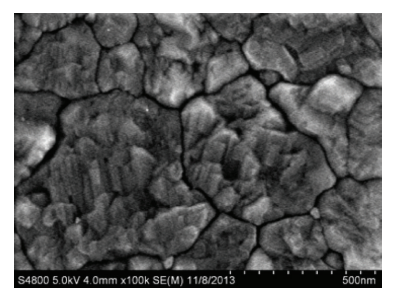

$3 \mathrm{~mA} / 50 \mathrm{sec}$

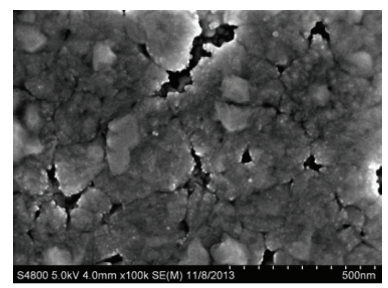

$5 \mathrm{~mA} / 50 \mathrm{sec}$

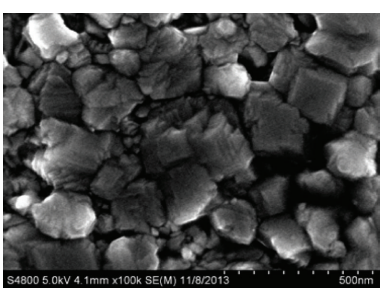

$3 \mathrm{~mA} / 60 \mathrm{sec}$

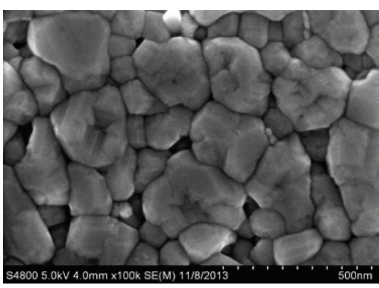

$5 \mathrm{~mA} / 60 \mathrm{sec}$

(d)

Figure 3: FESEM images of $\mathrm{WO}_{3}$ thin films, along with various process parameters: (a) as-deposited, (b) $T_{a}=250^{\circ} \mathrm{C}$, (c) $T_{a}=500^{\circ} \mathrm{C}$, and (d) $T_{a}=700^{\circ} \mathrm{C}$.

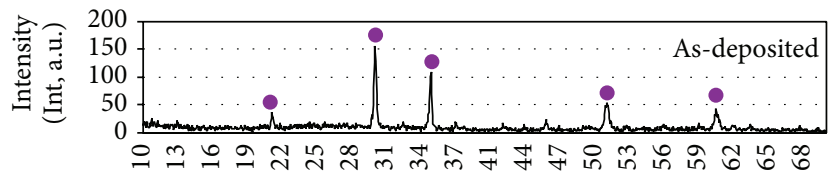

$2 \theta(2 \theta, \mathrm{deg})$

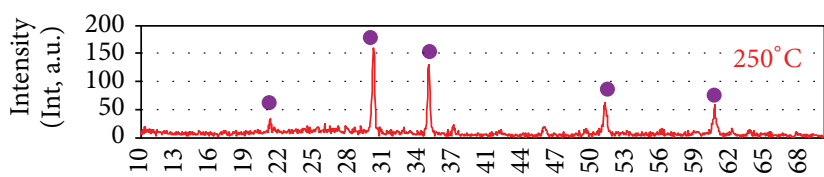

$2 \theta(2 \theta, \operatorname{deg})$

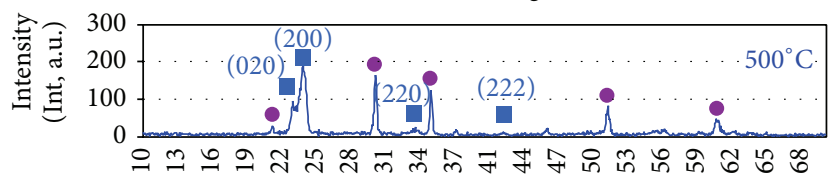

$2 \theta(2 \theta, \mathrm{deg})$

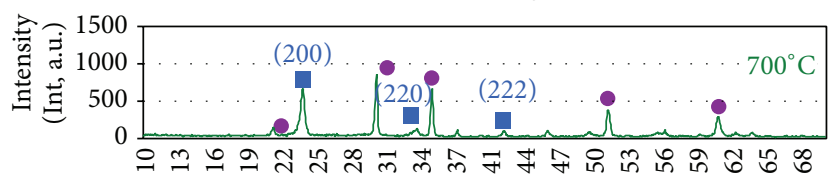

$2 \theta(2 \theta, \mathrm{deg})$

- ITO

- Anorthic

FIGURE 4: XRD pattern for the $\mathrm{WO}_{3}$-coated glass annealed at various $T_{a}$ and an $I_{\mathrm{ED}}$ of $3 \mathrm{~mA}$.

(sec), $I_{\mathrm{ED}}(\mathrm{mA})$, and $T_{a}\left({ }^{\circ} \mathrm{C}\right)$ were correlated with the $\mathrm{WO}_{3}$ thin-film thickness. The empirical formulas for the thickness of an as-deposited ( $\left.\mathrm{FT}_{\text {As-dep. }}, \mathrm{nm}\right)$ and annealed $\left(\mathrm{FT}_{\mathrm{An}}, \mathrm{nm}\right)$ $\mathrm{WO}_{3}$ thin film are expressed as (3) and (4), respectively. The corresponding $R^{2}$ values are 0.946 and 0.843 :

$$
\mathrm{FT}_{\text {As-dep. }}=2.154 t_{\mathrm{ED}}+35.125 I_{\mathrm{ED}}-94.855 \text {, }
$$
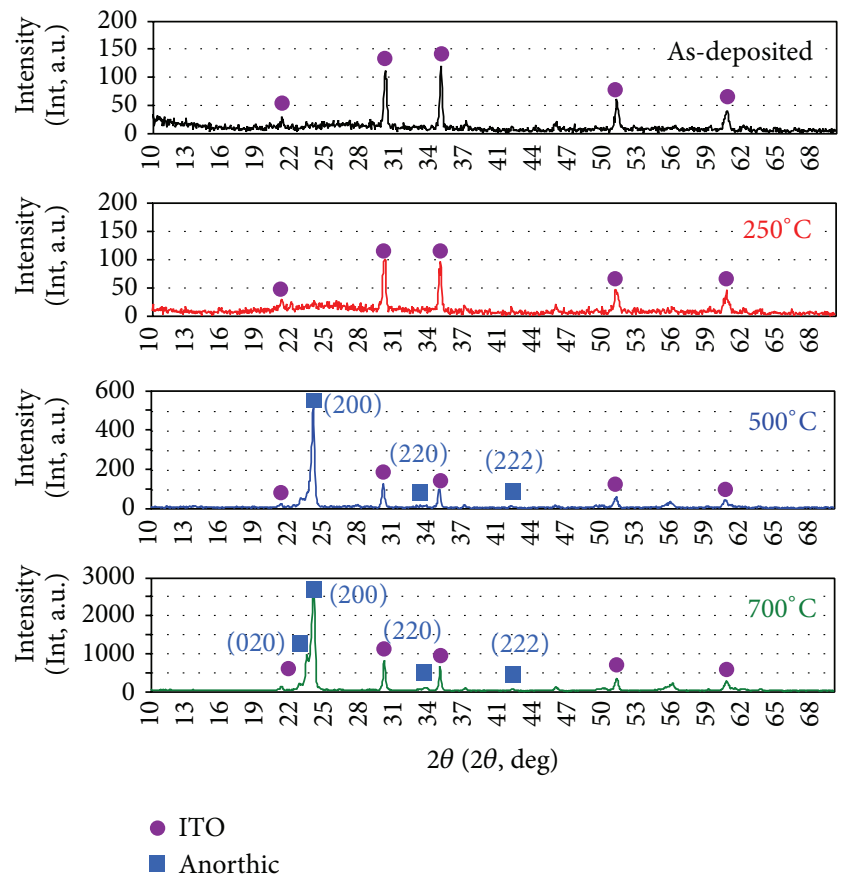

FIGURE 5: XRD pattern for the $\mathrm{WO}_{3}$-coated glass annealed at various $T_{a}$ and an $I_{\mathrm{ED}}$ of $5 \mathrm{~mA}$.

$$
\begin{aligned}
\mathrm{FT}_{\mathrm{An} .}= & 0.002 t_{\mathrm{ED}}^{2.5}+20.838 I_{\mathrm{ED}}+0.327 \mathrm{~T}_{a} \\
& -110.784 .
\end{aligned}
$$

Figures 8-10 show the transmittance, reflectivity, and absorptance of the $\mathrm{WO}_{3}$-coated glass and ITO glass for various values of the process parameters. Table 2 lists the average transmittance, reflectivity, and absorptance of the $\mathrm{WO}_{3}$-coated glass and ITO glass in VIS (400-760 nm) and NIR (760-2400 $\mathrm{nm}$ ) region for various values of the process 

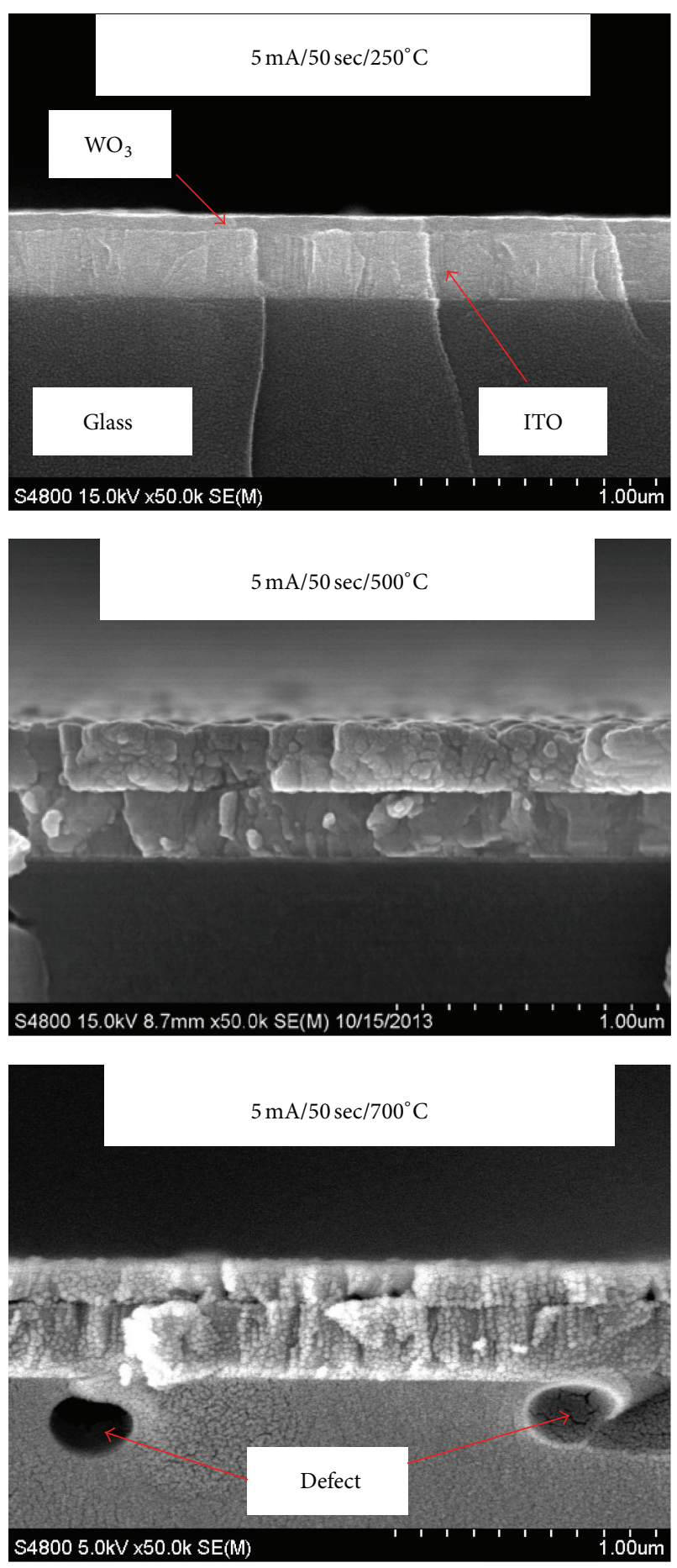

FIGURE 6: Cross-sectional FESEM image of the $\mathrm{WO}_{3}$-coated glass.

parameters. The transmittance, reflectivity, and absorptance of the $\mathrm{WO}_{3}$-coated glass and ITO glass show similar trends at a given $T_{a}$. In Figures 8(a), 8(b), 9(a), and 9(b), and Table 2, the amorphous $\mathrm{WO}_{3}$-coated glass and ITO glass $\left(T_{a} \leq 250^{\circ} \mathrm{C}\right)$ show high transmittance and low reflectivity in the VIS region. However, the transmittance decreases but the reflectivity increases as the wavelength increases in the NIR region. The experimental results for the transmittance of the

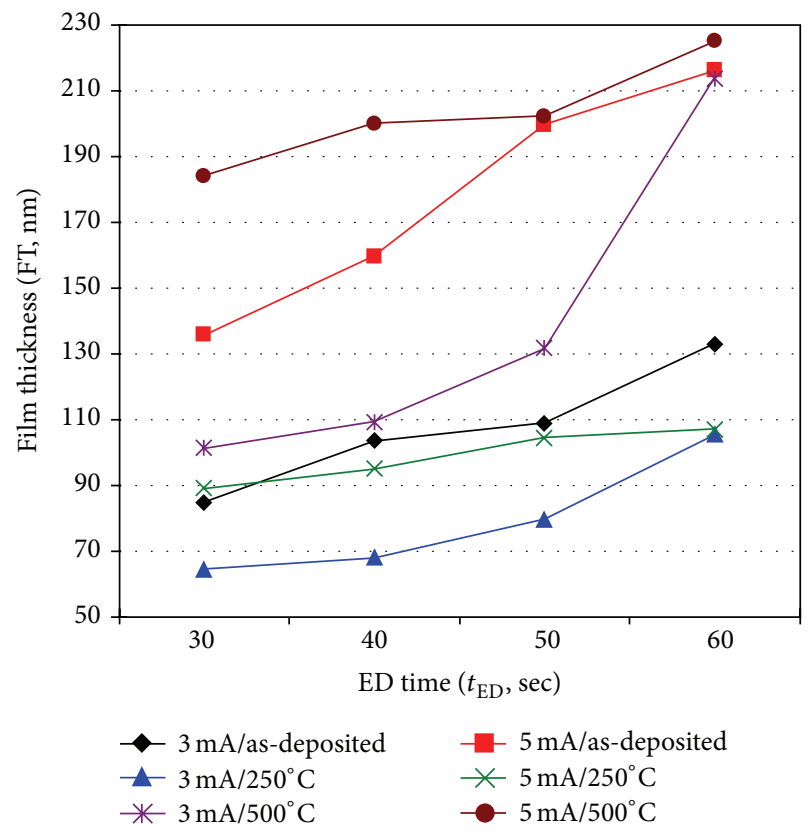

FIGURE 7: Variation of the $\mathrm{WO}_{3}$ film thickness with various process parameters.

amorphous $\mathrm{WO}_{3}$-coated glass are in accordance with trends reported in the literature $[3,6]$.

The oscillations of amorphous $\mathrm{WO}_{3}$-coated glass in the VIS region, which are associated with interferences between atomic layers, indicate the good quality of the $\mathrm{WO}_{3}$ thin films [6]. The experimental results demonstrate that values of average transmittance of the amorphous $\mathrm{WO}_{3}$-coated glass are $76.6 \%$ to $82.9 \%$ and $21.3 \%$ to $26.1 \%$ in the VIS and NIR regions, respectively; values of average reflectivity of the amorphous $\mathrm{WO}_{3}$-coated glass are $11.4 \%$ to $17.8 \%$ and $43.4 \%$ to $49.8 \%$ in the VIS and NIR regions, respectively.

In Figures 8(c) and 9(c) and Table 2, the transmittance of the $\mathrm{WO}_{3}$-coated glass annealed at $500^{\circ} \mathrm{C}$ in the VIS region is slightly lower than that of the amorphous $\mathrm{WO}_{3}$-coated glass, but the transmittance and reflectivity of $\mathrm{WO}_{3}$-coated glass $\left(T_{a}=500^{\circ} \mathrm{C}\right)$ in the NIR region are, respectively, much higher and lower than those of the amorphous $\mathrm{WO}_{3}$ coated glass, showing that anorthic $\mathrm{WO}_{3}$ thin films have high transparency in NIR light [2]. In addition, the average reflectivity of the anorthic $\mathrm{WO}_{3}$-coated glass is at least $17.8 \%$ lower than that of the amorphous $\mathrm{WO}_{3}$-coated glass in the NIR region. The experimental results demonstrate that values of average transmittance of the anorthic $\mathrm{WO}_{3}$-coated glass are $74.8 \%$ to $77.6 \%$ and $58.5 \%$ to $69.0 \%$ in the VIS and NIR regions, respectively; values of average reflectivity of the anorthic $\mathrm{WO}_{3}$-coated glass are $16.1 \%$ to $18.8 \%$ and $9.7 \%$ to $25.6 \%$ in the VIS and NIR regions, respectively.

In Figure 10 and Table 2, the average absorptance of the amorphous $\mathrm{WO}_{3}$-coated glass samples (as-deposited and annealed at $250^{\circ} \mathrm{C}$ ) is less than $6.5 \%$ in the VIS region, and the absorptance gradually increases in oscillations at wavelengths in the NIR region. However, the average absorptance of the anorthic $\mathrm{WO}_{3}$-coated glass $\left(T_{a}=500^{\circ} \mathrm{C}\right)$ is less than 

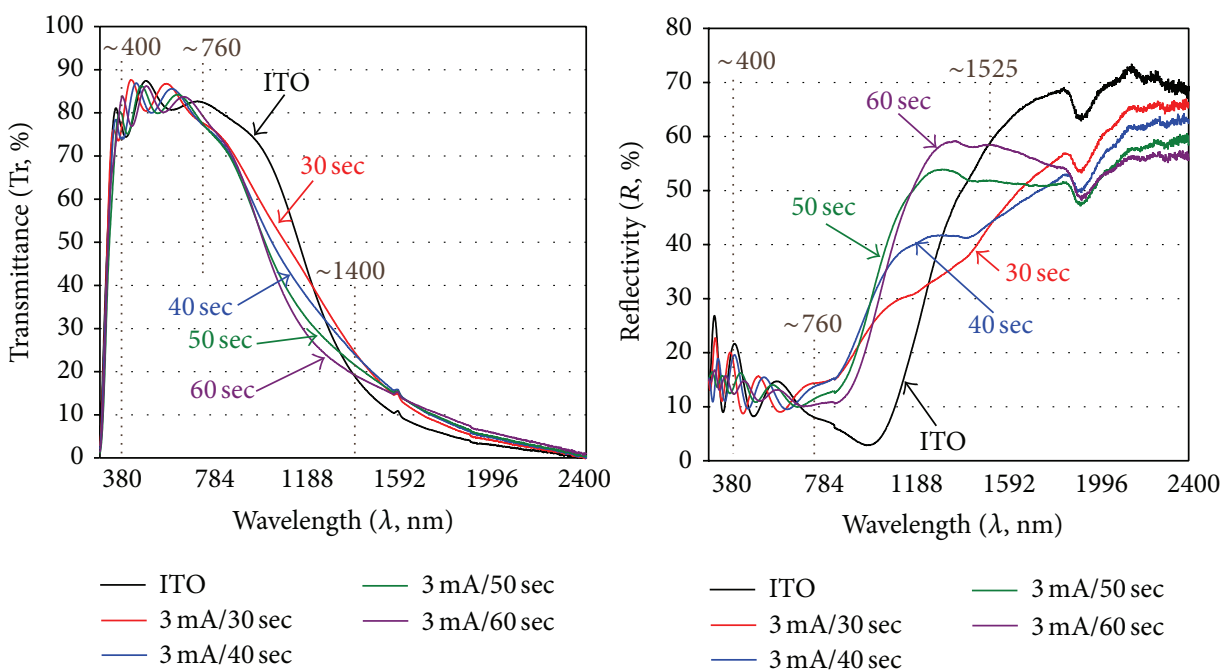

(a)
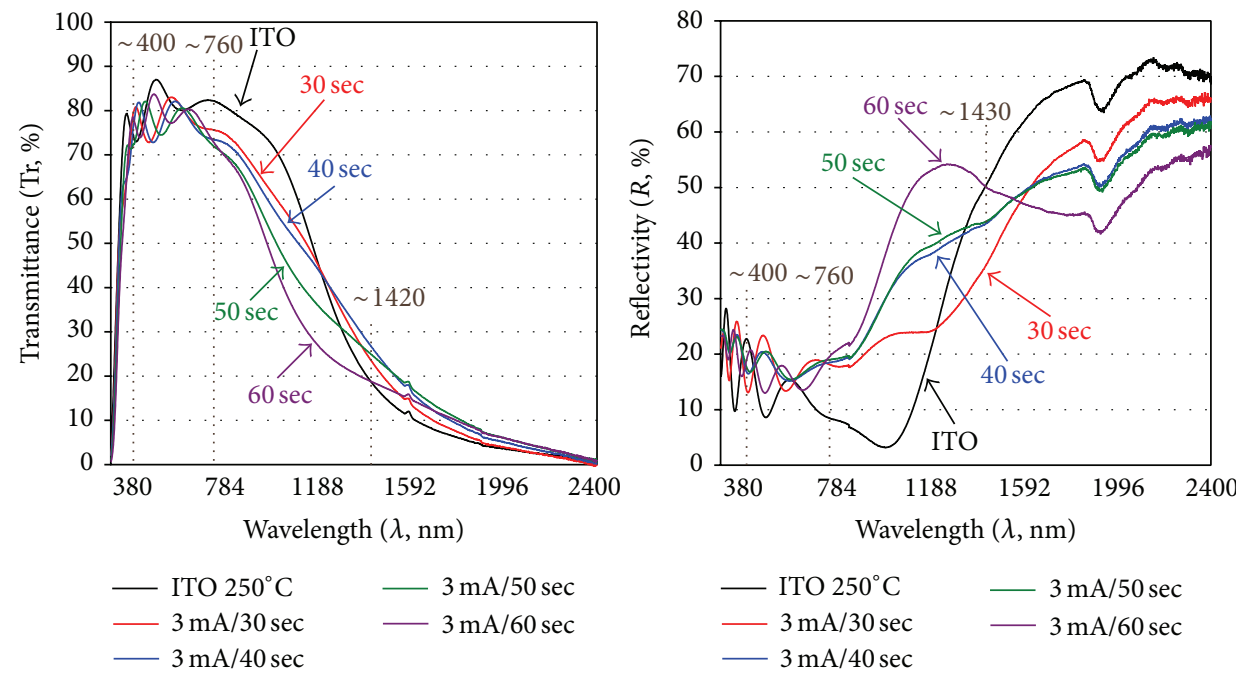

(b)
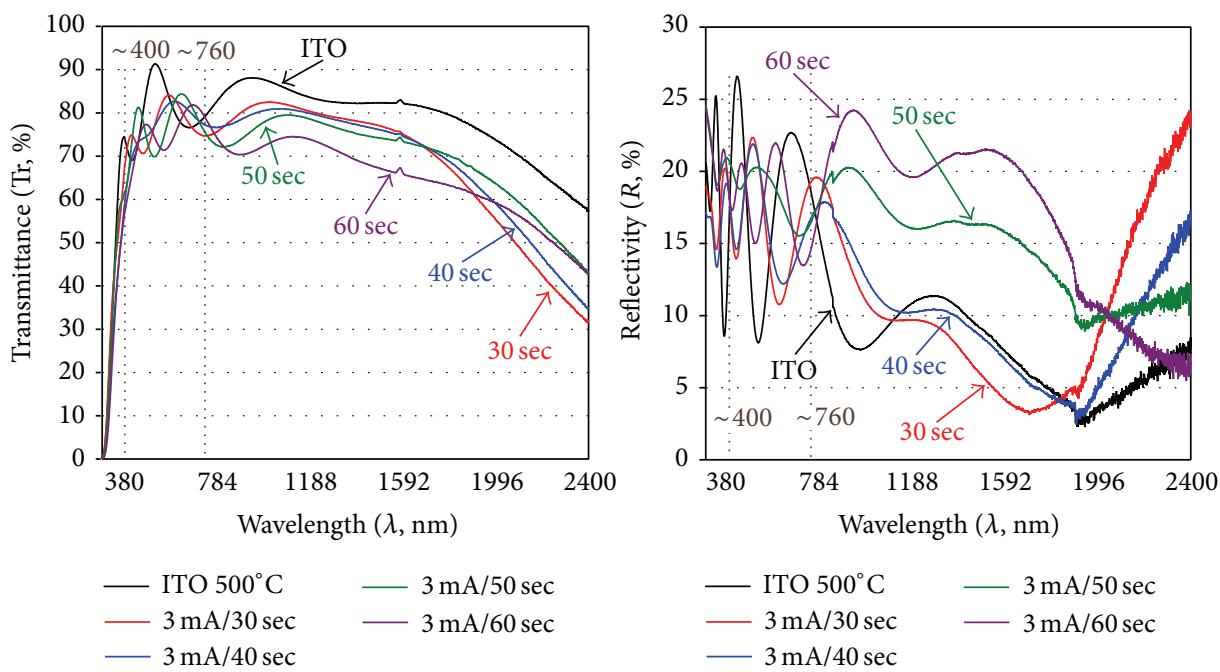

(c)

FIGURE 8: Transmittance and reflectivity of the $\mathrm{WO}_{3}$-coated glass and ITO glass annealed at various $T_{a}$ and at an $I_{\mathrm{ED}}$ of $3 \mathrm{~mA}$ : (a) as-deposited, (b) $T_{a}=250^{\circ} \mathrm{C}$, and (c) $T_{a}=500^{\circ} \mathrm{C}$. 

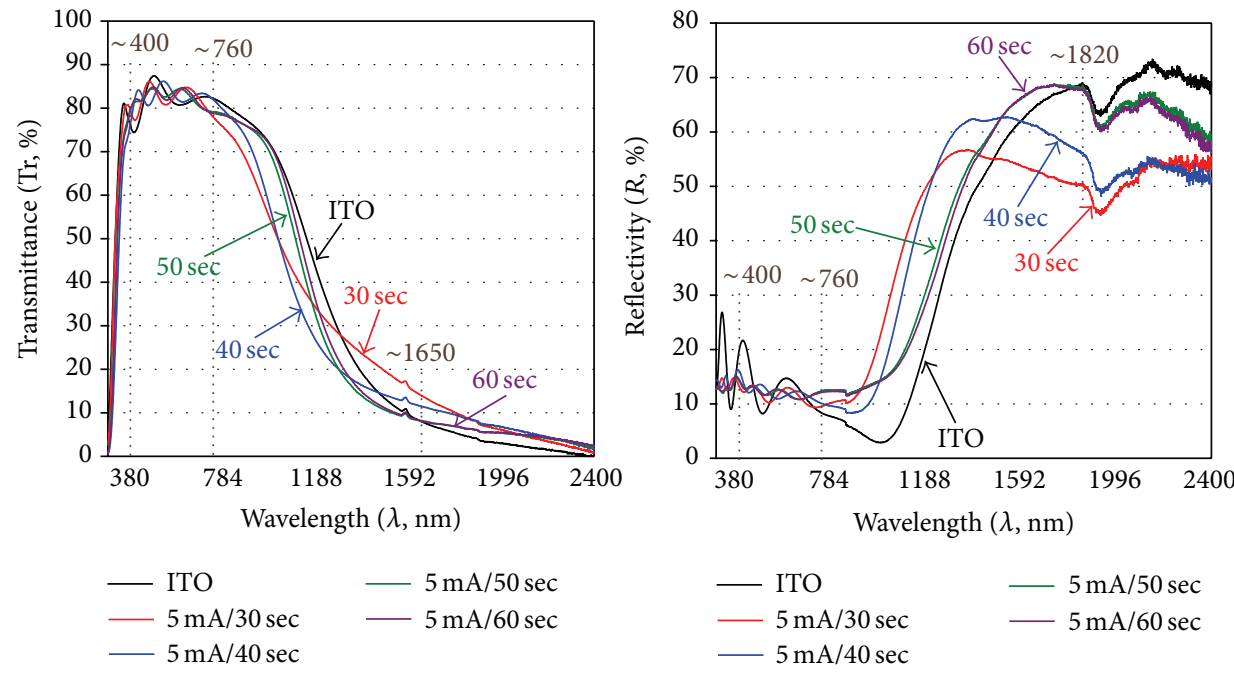

(a)
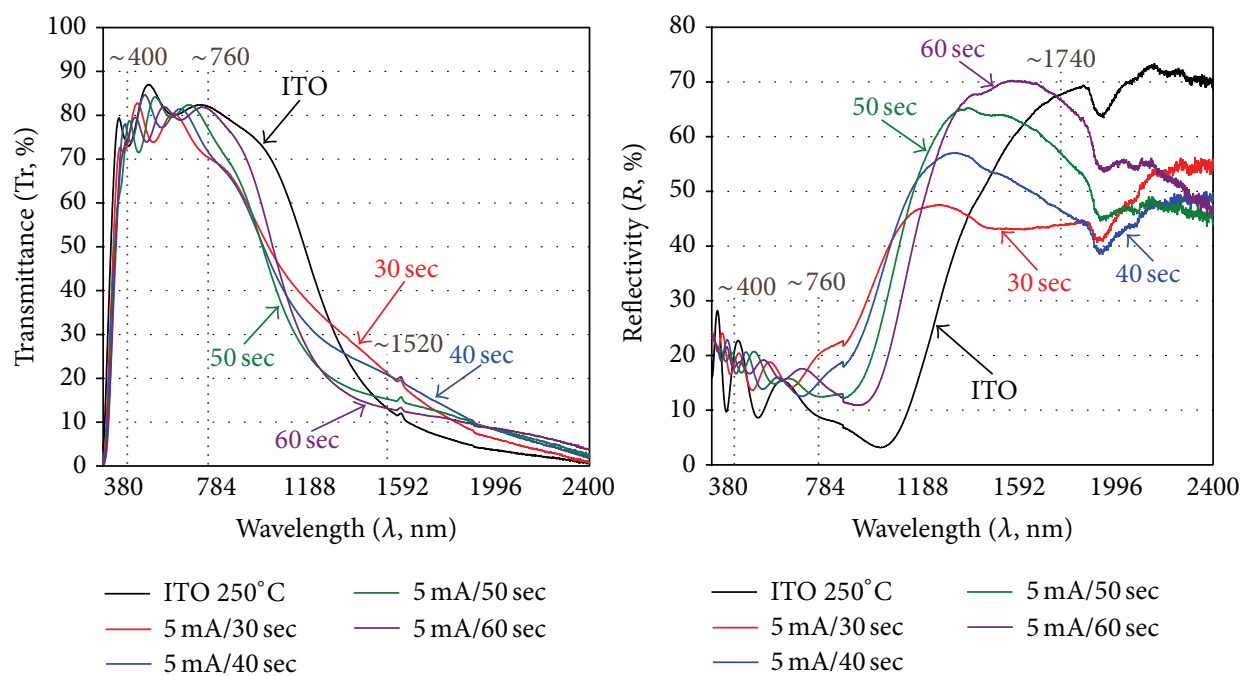

(b)
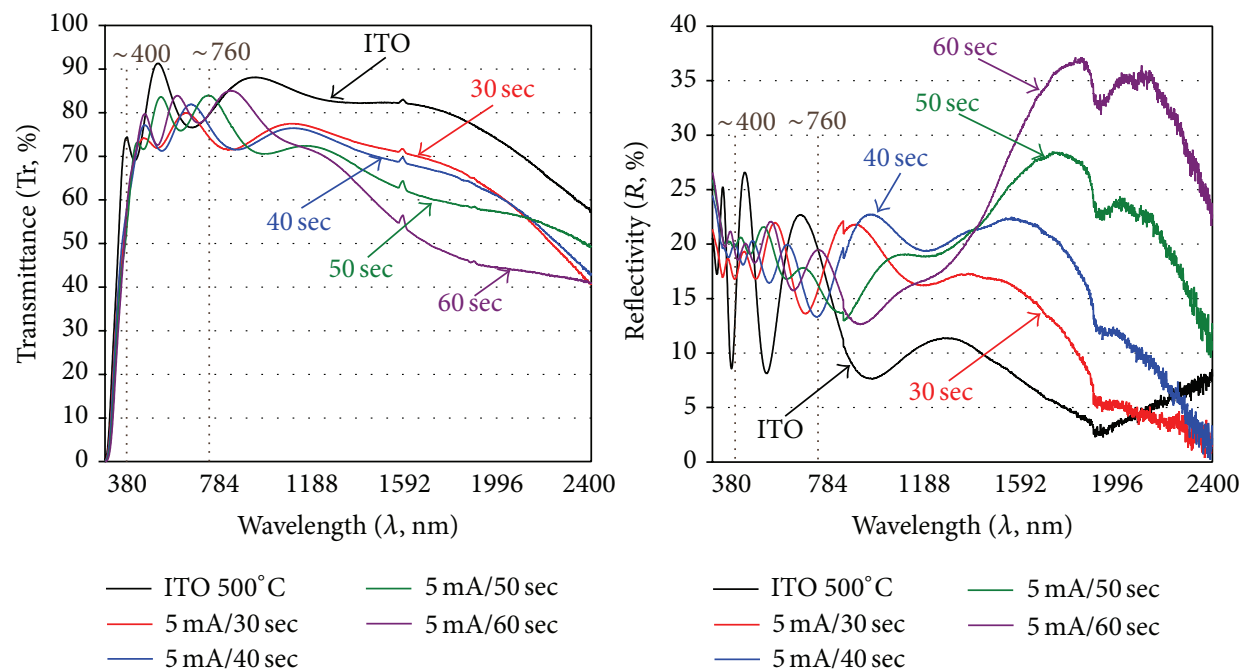

(c)

FIGURE 9: Transmittance and reflectivity of the $\mathrm{WO}_{3}$-coated glass and ITO glass annealed at various $T_{a}$ and at an $I_{\mathrm{ED}}$ of $5 \mathrm{~mA}$ : (a) as-deposited, (b) $T_{a}=250^{\circ} \mathrm{C}$, and (c) $T_{a}=500^{\circ} \mathrm{C}$. 

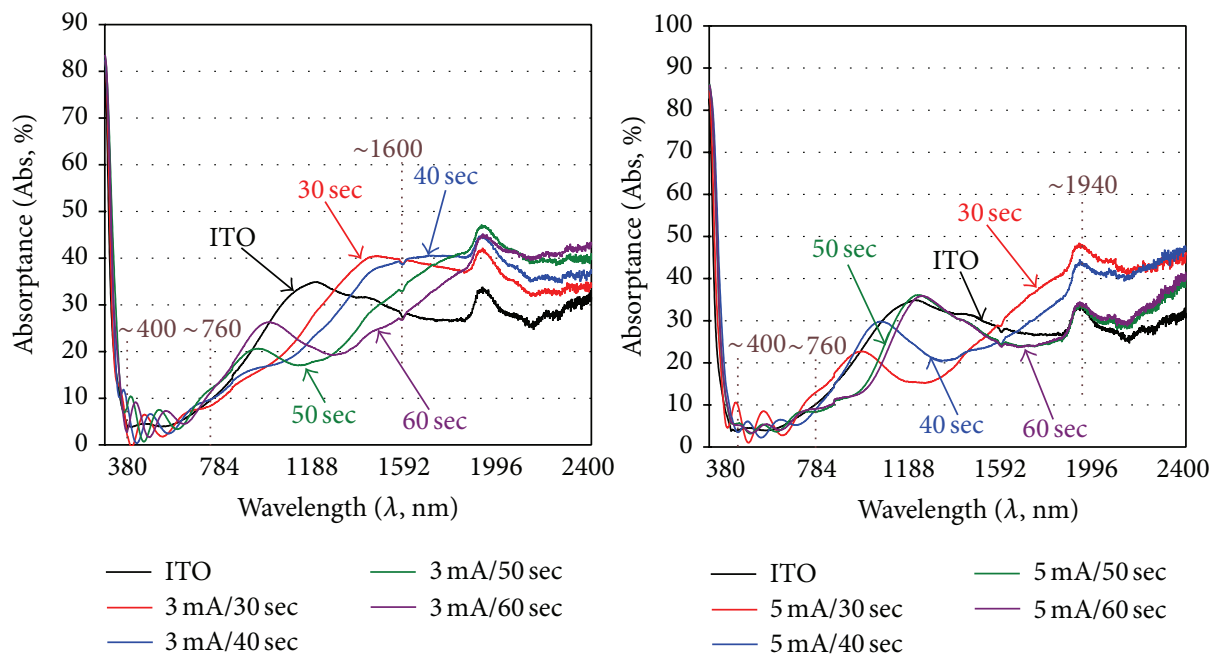

(a)
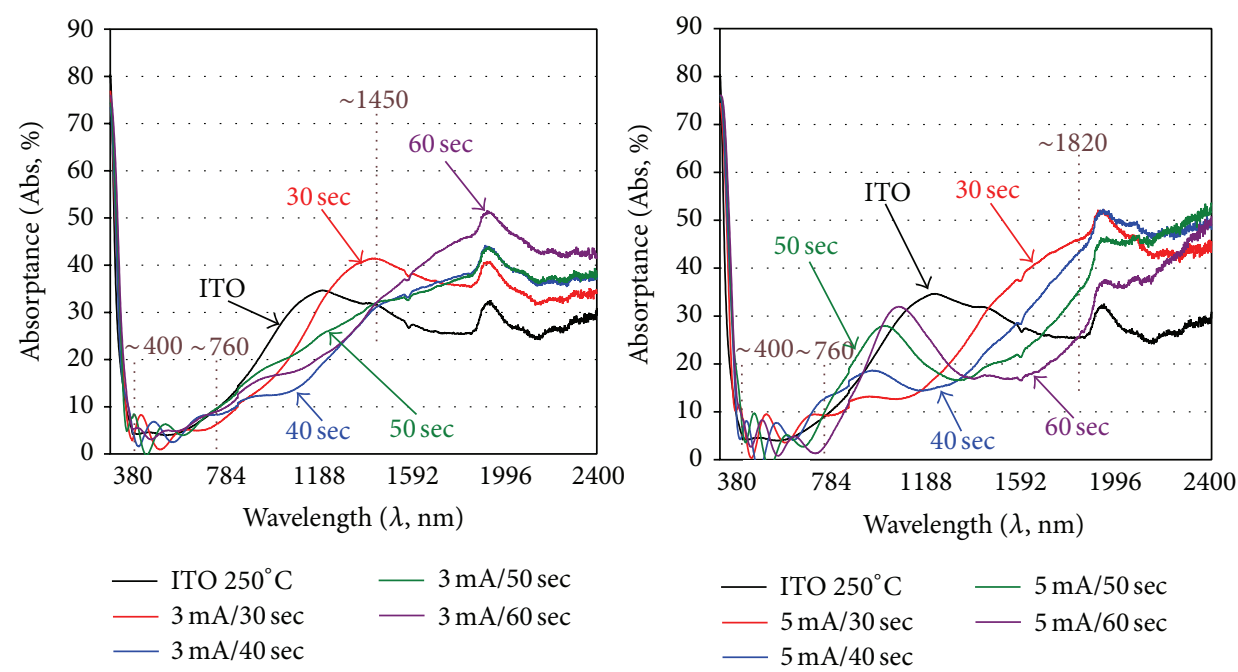

(b)
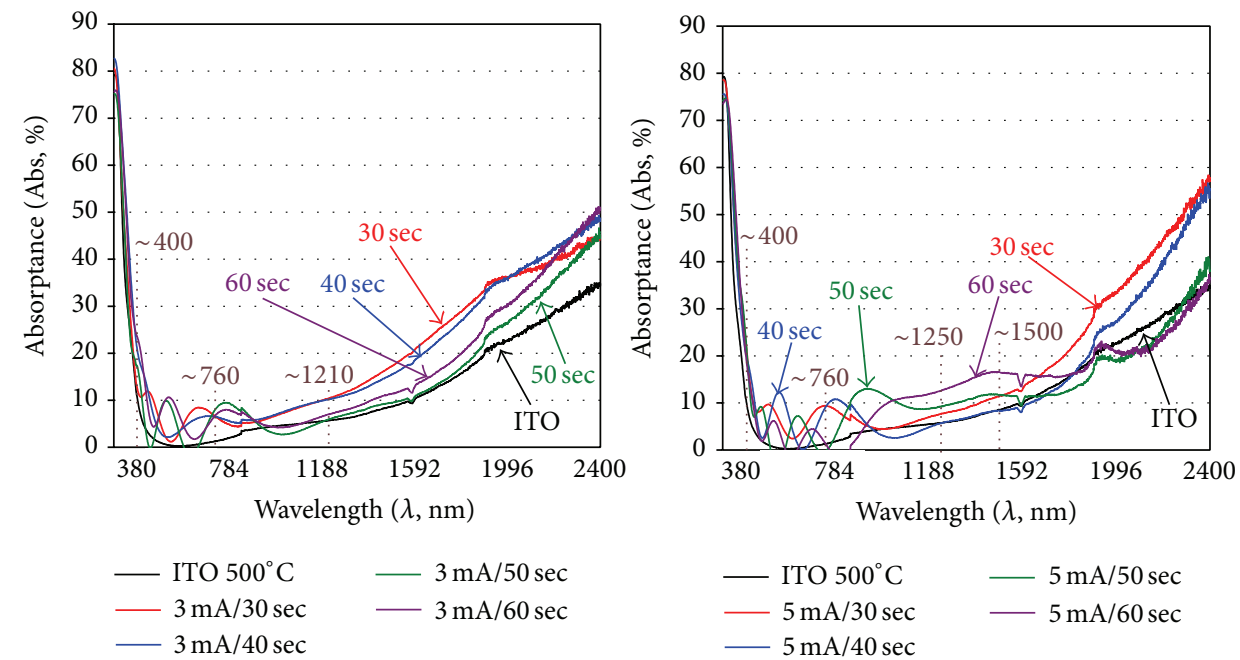

(c)

FIGURE 10: Absorptance of the $\mathrm{WO}_{3}$-coated glass and ITO glass at various values of the process parameters: (a) as-deposited, (b) $T_{a}=250^{\circ} \mathrm{C}$, and (c) $T_{a}=500^{\circ} \mathrm{C}$. 
TABLE 2: The average transmittance, reflectivity, and absorptance of the test samples.

\begin{tabular}{|c|c|c|c|c|c|c|c|c|c|c|c|c|}
\hline \multirow{3}{*}{ Items } & \multirow{3}{*}{ Annealing temperature } & \multirow{3}{*}{ Region } & \multirow{3}{*}{$\begin{array}{c}I_{\mathrm{ED}}(\mathrm{mA}) \\
t_{\mathrm{ED}}(\mathrm{sec})\end{array}$} & \multirow{3}{*}{$\begin{array}{c}\text { ITO } \\
- \\
- \\
\end{array}$} & \multicolumn{8}{|c|}{$\mathrm{WO}_{3}$-coated glass } \\
\hline & & & & & \multicolumn{4}{|c|}{3} & \multicolumn{4}{|c|}{5} \\
\hline & & & & & 30 & 40 & 50 & 60 & 30 & 40 & 50 & 60 \\
\hline \multirow{6}{*}{ Transmittance (\%) } & As-deposited & \multirow{3}{*}{ VIS } & & 82.0 & 82.7 & 81.9 & 81.3 & 81.8 & 82.1 & 82.9 & 82.3 & 82.4 \\
\hline & 250 & & & 81.5 & 77.9 & 77.2 & 77.0 & 78.1 & 76.6 & 78.5 & 79.5 & 79.2 \\
\hline & 500 & & & 80.0 & 77.0 & 77.3 & 77.0 & 75.1 & 74.8 & 75.6 & 77.6 & 77.4 \\
\hline & As-deposited & \multirow{3}{*}{ NIR } & & 25.5 & 24.9 & 24.1 & 22.9 & 22.5 & 24.5 & 23.1 & 23.9 & 24.7 \\
\hline & 250 & & & 26.3 & 25.5 & 26.1 & 24.3 & 21.3 & 24.6 & 24.1 & 22.1 & 23.4 \\
\hline & 500 & & & 78.4 & 67.2 & 68.1 & 69.0 & 64.5 & 66.8 & 66.1 & 63.9 & 58.5 \\
\hline \multirow{6}{*}{ Reflectivity (\%) } & As-deposited & \multirow{3}{*}{ VIS } & & 12.6 & 12.3 & 12.7 & 12.4 & 12.0 & 11.4 & 12.0 & 12.1 & 12.0 \\
\hline & 250 & & & 13.1 & 17.5 & 17.4 & 17.8 & 16.2 & 16.9 & 15.3 & 16.0 & 17.2 \\
\hline & 500 & & & 18.4 & 16.2 & 16.1 & 18.3 & 17.6 & 17.7 & 17.5 & 18.6 & 18.8 \\
\hline & As-deposited & \multirow{3}{*}{ NIR } & & 46.7 & 44.0 & 44.5 & 46.5 & 47.3 & 45.2 & 46.7 & 49.3 & 48.4 \\
\hline & 250 & & & 46.6 & 43.4 & 45.4 & 45.2 & 45.8 & 43.4 & 44.5 & 47.3 & 49.8 \\
\hline & 500 & & & 7.7 & 10.6 & 9.7 & 14.6 & 16.7 & 12.7 & 16.6 & 20.9 & 25.6 \\
\hline \multirow{6}{*}{ Absorptance (\%) } & As-deposited & \multirow{3}{*}{ VIS } & & 5.4 & 4.9 & 5.4 & 6.4 & 6.2 & 6.5 & 5.2 & 5.6 & 5.6 \\
\hline & 250 & & & 5.4 & 4.5 & 5.4 & 5.2 & 5.7 & 6.5 & 6.2 & 4.5 & 3.7 \\
\hline & 500 & & & 1.5 & 6.8 & 6.6 & 4.7 & 7.2 & 7.6 & 6.9 & 3.7 & 3.8 \\
\hline & As-deposited & \multirow{3}{*}{\multicolumn{2}{|c|}{ NIR }} & 27.8 & 31.1 & 31.4 & 30.7 & 30.2 & 30.3 & 30.2 & 26.8 & 26.8 \\
\hline & 250 & & & 27.1 & 31.1 & 28.6 & 30.5 & 32.8 & 32.0 & 31.4 & 30.6 & 26.8 \\
\hline & 500 & & & 13.9 & 22.2 & 22.1 & 16.4 & 18.8 & 20.6 & 17.3 & 15.2 & 16.0 \\
\hline
\end{tabular}

$7.6 \%$ in the VIS region, and the absorptance increases in a relatively stable state with the wavelength in the NIR region, unlike the amorphous $\mathrm{WO}_{3}$-coated glass. The experimental results demonstrate that values of average absorptance of the amorphous $\mathrm{WO}_{3}$-coated glass are $3.7 \%$ to $6.5 \%$ and $26.8 \%$ to $32.8 \%$ in the VIS and NIR regions, respectively; values of average absorptance of the anorthic $\mathrm{WO}_{3}$-coated glass are $3.7 \%$ to $7.6 \%$ and $15.2 \%$ to $22.2 \%$ in the VIS and NIR regions, respectively.

Although the transmittance, reflectivity, and absorptance of the $\mathrm{WO}_{3}$-coated glass samples fabricated at various $t_{\mathrm{ED}}$ and $I_{\mathrm{ED}}$ with the same $T_{a}$ show similar trends, they also display considerable differences at the same wavelength. The main reason for these differences is that the film thickness and surface roughness of the multilayered $\mathrm{WO}_{3}$-coated glass samples varied with the $I_{\mathrm{ED}}$ and $t_{\mathrm{ED}}$. The thickness of the thin film causes constructive or destructive interference of incident light, which affects both transmission and reflection spectrum. Moreover, surface roughness cause incident light scattering and thus affects both transmission and reflection spectrum.

\section{Conclusions}

$\mathrm{WO}_{3}$ thin films were successfully prepared on ITO glass substrates through ED with various $I_{\mathrm{ED}}, t_{\mathrm{ED}}$, and $T_{a}$ settings, and their characteristics were determined using appropriate instruments and test methods. The findings of this study are summarized as follows:

(1) To prepare $\mathrm{WO}_{3}$-coated glass through $\mathrm{ED}$, the optimal $I_{\mathrm{ED}}$ were $3-5 \mathrm{~mA}$ at various $t_{\mathrm{ED}}(30-60 \mathrm{~s})$, and $T_{a}$ less than $500^{\circ} \mathrm{C}$ can avoid damage and defects in the substrate (ITO glass).

(2) The $\mathrm{WO}_{3}$ film thickness increased with $t_{\mathrm{ED}}$ and $I_{\mathrm{ED}}$. However, $T_{a}$ also notably affected the $\mathrm{WO}_{3}$ film thickness.

(3) The as-deposited $\mathrm{WO}_{3}$ thin films and $\mathrm{WO}_{3}$ thin films annealed at $250^{\circ} \mathrm{C}$ were amorphous. By contrast, $\mathrm{WO}_{3}$ thin films annealed at 500 and $700^{\circ} \mathrm{C}$ were in the anorthic phase.

(4) The amorphous $\mathrm{WO}_{3}$-coated glass had high transmittance in VIS light and low transmittance in NIR light. However, the anorthic $\mathrm{WO}_{3}$-coated glass had high transmittance in NIR light.

(5) Multiple regression and ED process parameters were used to derive an empirical formula for determining the thickness of $\mathrm{WO}_{3}$ thin films.

(6) The amorphous $\mathrm{WO}_{3}$ thin films are typically used in an electrochromic device. In addition, the amorphous and uneven crystalline $\mathrm{WO}_{3}$ thin films can also be applied to the fields of spectral selection, gas sensors, lithium-ion battery electrodes, antiwear coating, and catalysis according to its characteristics (e.g., uneven surface of $\mathrm{WO}_{3}$ thin film may benefit reaction with external substances).

\section{Competing Interests}

The authors declare that there is no conflict of interests regarding the publication of this paper. 


\section{Acknowledgments}

The authors would like to thank National Science Council of the Republic of China, for their financial support to this research under Contract no. NSC 102-2221-E-003-006-.

\section{References}

[1] M. Deepa, A. K. Srivastava, T. K. Saxena, and S. A. Agnihotry, "Annealing induced microstructural evolution of electrodeposited electrochromic tungsten oxide films," Applied Surface Science, vol. 252, no. 5, pp. 1568-1580, 2005.

[2] M. Deepa, A. K. Srivastava, S. Lauterbach, Govind, S. M. Shivaprasad, and K. N. Sood, "Electro-optical response of tungsten oxide thin film nanostructures processed by a template-assisted electrodeposition route," Acta Materialia, vol. 55, no. 18, pp. 6095-6107, 2007.

[3] M. Deepa, A. K. Srivastava, S. N. Sharma, Govind, and S. M. Shivaprasad, "Microstructural and electrochromic properties of tungsten oxide thin films produced by surfactant mediated electrodeposition," Applied Surface Science, vol. 254, no. 8, pp. 2342-2352, 2008.

[4] K. A. Gesheva, T. M. Ivanova, and G. Bodurov, "Transition metal oxide films: technology and Smart Windows electrochromic device performance," Progress in Organic Coatings, vol. 74, no. 4, pp. 635-639, 2012.

[5] C.-K. Wang, C.-K. Lin, C.-L. Wu, S. Brahma, S.-C. Wang, and J.L. Huang, "Characterization of electrochromic tungsten oxide film from electrochemical anodized RF-sputtered tungsten films," Ceramics International, vol. 39, no. 4, pp. 4293-4298, 2013.

[6] Ö. Tuna, A. Sezgin, R. Budakoğlu, S. Türküz, and H. Parlar, "Electrochromic properties of tungsten trioxide $\left(\mathrm{WO}_{3}\right)$ layers grown on ITO/glass substrates by magnetron sputtering," Vacuum B, vol. 120, pp. 28-31, 2015.

[7] G. Gorgolis and D. Karamanis, "Solar energy materials for glazing technologies," Solar Energy Materials and Solar Cells, vol. 144, pp. 559-578, 2016.

[8] J. Georgieva, E. Valova, S. Armyanov, N. Philippidis, I. Poulios, and S. Sotiropoulos, "Bi-component semiconductor oxide photoanodes for the photoelectrocatalytic oxidation of organic solutes and vapours: a short review with emphasis to $\mathrm{TiO}_{2}-$ $\mathrm{WO}_{3}$ photoanodes," Journal of Hazardous Materials, vol. 211212, pp. 30-46, 2012.

[9] S. S. Thind, K. Rozic, F. Amano, and A. Chen, "Fabrication and photoelectrochemical study of $\mathrm{WO}_{3}$-based bifunctional electrodes for environmental applications," Applied Catalysis B: Environmental, vol. 176-177, pp. 464-471, 2015.

[10] S. Ghosh, S. S. Acharyya, R. Singh, P. Gupta, and R. Bal, "Fabrication of $\mathrm{Ag} / \mathrm{WO}_{3}$ nanobars for Baeyer-Villiger oxidation using hydrogen peroxide," Catalysis Communications, vol. 72, pp. 33-37, 2015.

[11] X. Wang, L. Pang, X. Hu, and N. Han, "Fabrication of ion doped $\mathrm{WO}_{3}$ photocatalysts through bulk and surface doping," Journal of Environmental Sciences, vol. 35, pp. 76-82, 2015.

[12] S. Ashraf, C. S. Blackman, R. G. Palgrave, and I. P. Parkin, "Aerosol-assisted chemical vapour deposition of $\mathrm{WO}_{3}$ thin films using polyoxometallate precursors and their gas sensing properties," Journal of Materials Chemistry, vol. 17, no. 11, pp. 1063-1070, 2007.

[13] K. Wetchakun, T. Samerjai, N. Tamaekong et al., "Semiconducting metal oxides as sensors for environmentally hazardous gases," Sensors and Actuators B: Chemical, vol. 160, no. 1, pp. 580-591, 2011.

[14] H. Y. Li, Z. X. Cai, J. C. Ding, and X. Guo, "Gigantically enhanced $\mathrm{NO}$ sensing properties of $\mathrm{WO}_{3} / \mathrm{SnO}_{2}$ double layer sensors with Pd decoration," Sensors and Actuators B: Chemical, vol. 220, pp. 398-405, 2015.

[15] J. Ollitrault, N. Martin, J.-Y. Rauch, J.-B. Sanchez, and F. Berger, "Improvement of ozone detection with GLAD $\mathrm{WO}_{3}$ films," Materials Letters, vol. 155, pp. 1-3, 2015.

[16] F. Li, C. Li, L. Zhu et al., "Enhanced toluene sensing performance of gold-functionalized $\mathrm{WO}_{3} \cdot \mathrm{H}_{2} \mathrm{O}$ nanosheets," Sensors and Actuators B: Chemical, vol. 223, pp. 761-767, 2016.

[17] W.-J. Li and Z.-W. Fu, "Nanostructured $\mathrm{WO}_{3}$ thin film as a new anode material for lithium-ion batteries," Applied Surface Science, vol. 256, no. 8, pp. 2447-2452, 2010.

[18] L. Gao, X. Wang, Z. Xie et al., "High performance energystorage devices based on $\mathrm{WO}_{3}$ nanowire arrays/carbon cloth integrated electrodes," Journal of Materials Chemistry A, vol. 1, no. 24, pp. 7167-7173, 2013.

[19] L. Gao, F. Qu, and X. Wu, "Hierarchical $\mathrm{WO}_{3} @ \mathrm{SnO}_{2}$ coreshell nanowire arrays on carbon cloth: a new class of anode for high-performance lithium-ion batteries," Journal of Materials Chemistry A, vol. 2, no. 20, pp. 7367-7372, 2014.

[20] S. K. Park, H. J. Lee, M. H. Lee, and H. S. Park, "Hierarchically structured reduced graphene oxide $/ \mathrm{WO}_{3}$ frameworks for an application into lithium ion battery anodes," Chemical Engineering Journal, vol. 281, pp. 724-729, 2015.

[21] O. D. Greenwood, S. C. Moulzolf, P. J. Blau, and R. J. Lad, “The influence of microstructure on tribological properties of $\mathrm{WO}_{3}$ thin films," Wear, vol. 232, no. 1, pp. 84-90, 1999.

[22] P. Harlin, P. Carlsson, U. Bexell, and M. Olsson, "Influence of surface roughness of PVD coatings on tribological performance in sliding contacts," Surface and Coatings Technology, vol. 201, no. 7, pp. 4253-4259, 2006.

[23] V. Totolin, M. Rodríguez Ripoll, M. Jech, and B. Podgornik, "Enhanced tribological performance of tungsten carbide functionalized surfaces via in-situ formation of low-friction tribofilms," Tribology International, vol. 94, pp. 269-278, 2016.

[24] S. Ashraf, C. S. Blackman, S. C. Naisbitt, and I. P. Parkin, "The gas-sensing properties of WO3-x thin films deposited via the atmospheric pressure chemical vapour deposition (APCVD) of WCl6 with ethanol," Measurement Science and Technology, vol. 19, no. 2, Article ID 025203, 2008.

[25] E. A. Meulenkamp, "Mechanism of $\mathrm{WO}_{3}$ electrodeposition from peroxy-tungstate solution," Journal of the Electrochemical Society, vol. 144, no. 5, pp. 1664-1671, 1997.

[26] Y. O. Kim, S. Yu, K. Ahn, S. K. Lee, and S. H. Kang, "Enhancing the photoresponse of electrodeposited $\mathrm{WO}_{3}$ film: structure and thickness effect," Journal of Electroanalytical Chemistry, vol. 752, pp. 25-32, 2015.

[27] A. J. More, R. S. Patil, D. S. Dalavi et al., "Electrodeposition of nano-granular tungsten oxide thin films for smart window application," Materials Letters, vol. 134, pp. 298-301, 2014.

[28] K. P. S. S. Hembram, R. Thomas, and G. M. Rao, "Microstructural evolution of tungsten oxide thin films," Applied Surface Science, vol. 256, no. 2, pp. 419-422, 2009.

[29] Y. Fang, W. C. Lee, G. E. Canciani et al., "Thickness control in electrophoretic deposition of $\mathrm{WO}_{3}$ nanofiber thin films for solar water splitting," Materials Science and Engineering B: Solid-State Materials for Advanced Technology, vol. 202, Article ID 13793, pp. 39-45, 2015. 

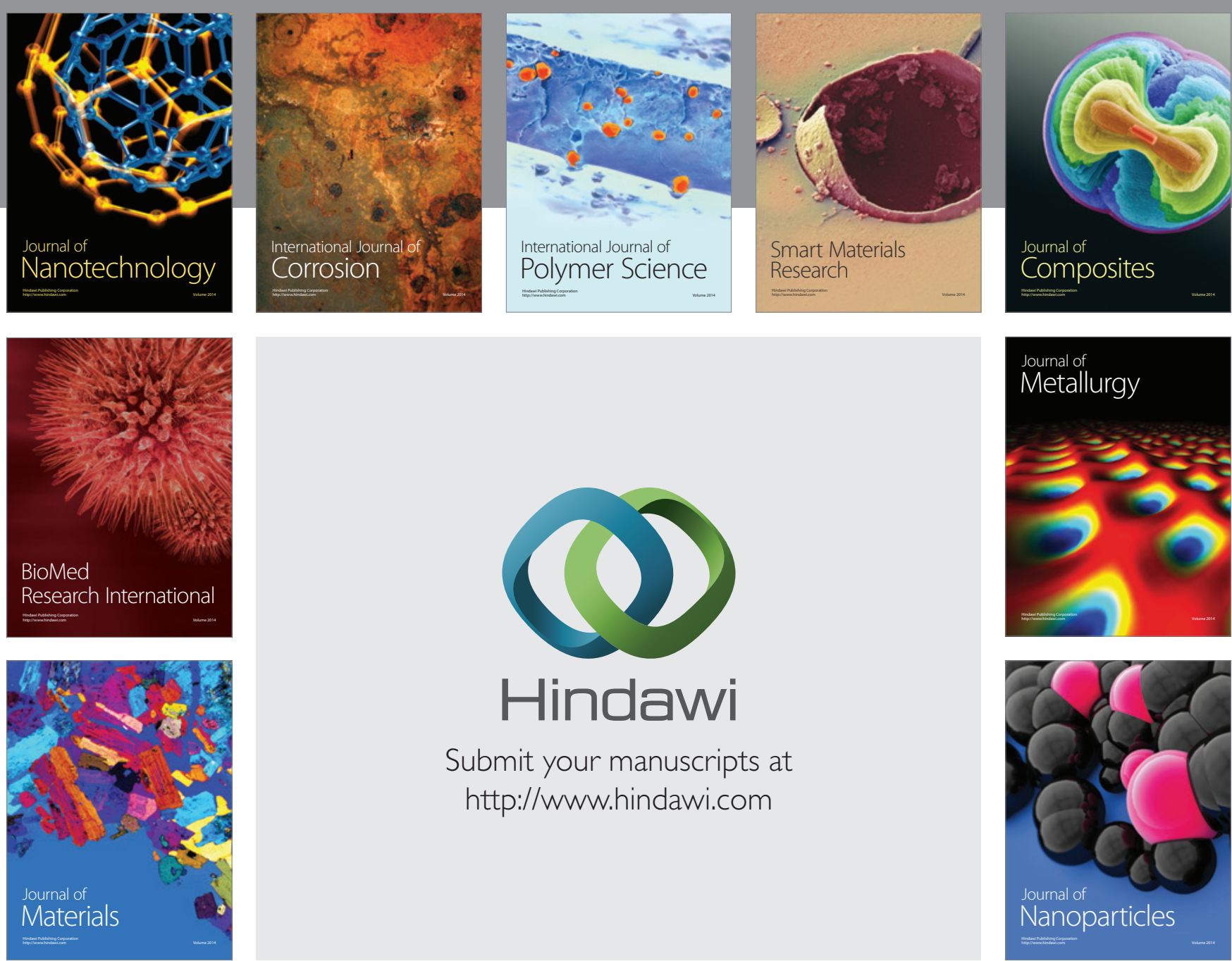

\section{Hindawi}

Submit your manuscripts at

http://www.hindawi.com

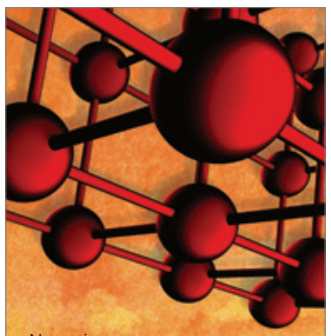

Materials Science and Engineering
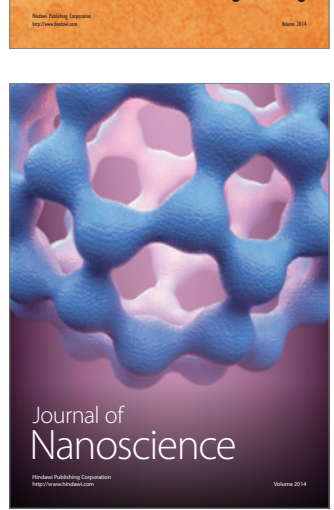
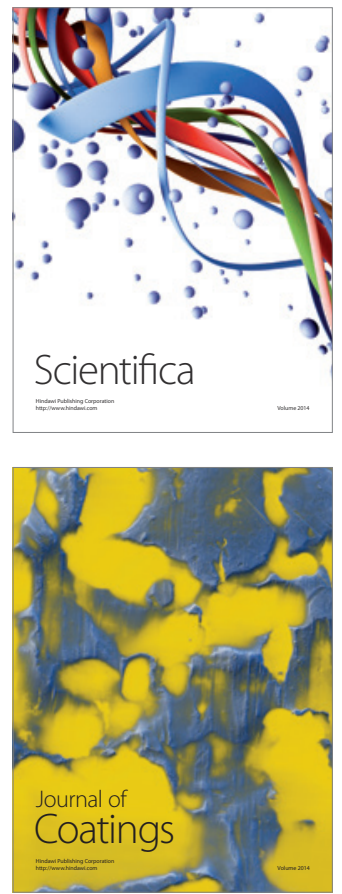
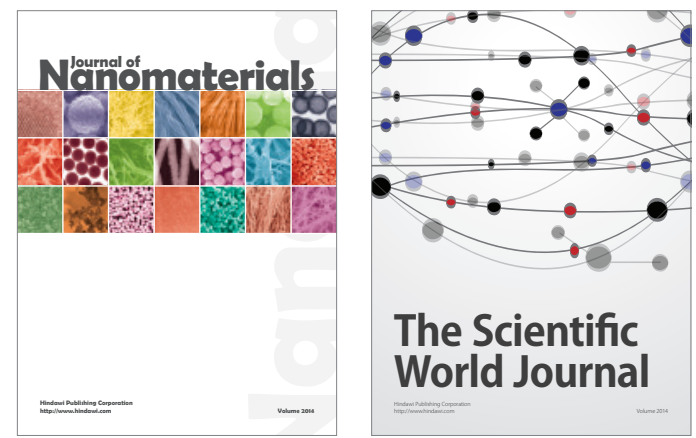

The Scientific World Journal
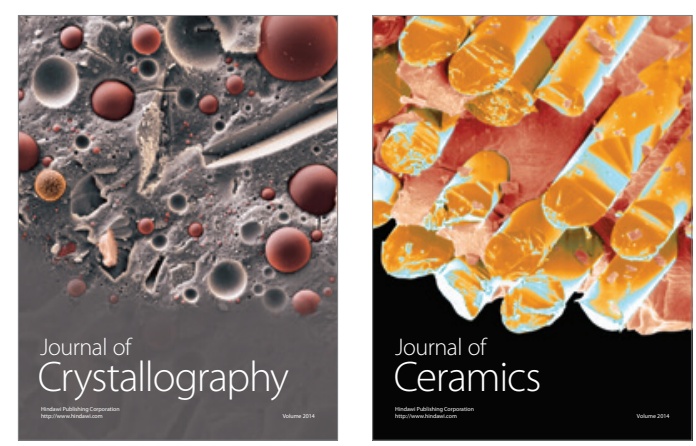
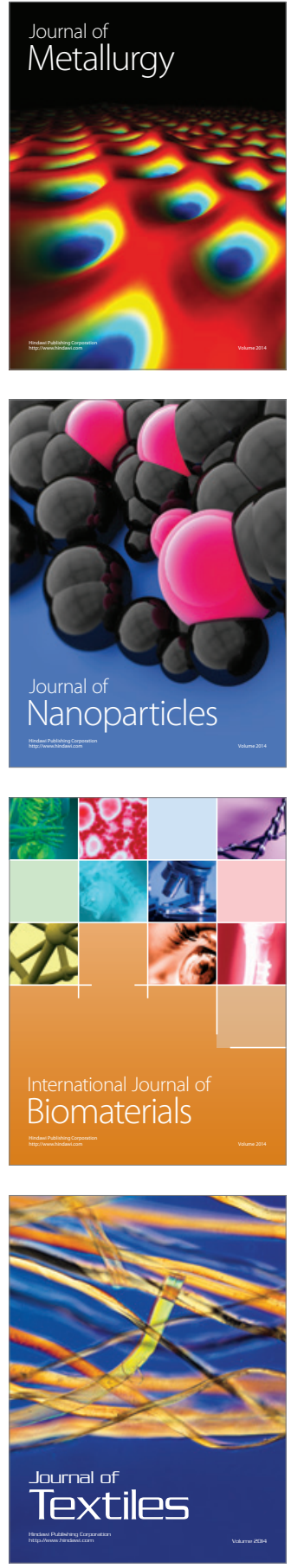